\title{
Marine Proteobacteria as a source of natural products: advances in molecular tools and strategies
}

Buijs, Yannick; Bech, Pernille Kjersgaard; Vazquez Albacete, Dario; Bentzon-Tilia, Mikkel; Sonnenschein, Eva C.; Gram, Lone; Zhang, Sheng-Da

Published in:

Natural Product Reports

Link to article, DOI:

10.1039/c9np00020h

Publication date:

2019

Document Version

Peer reviewed version

Link back to DTU Orbit

Citation (APA):

Buijs, Y., Bech, P. K., Vazquez Albacete, D., Bentzon-Tilia, M., Sonnenschein, E. C., Gram, L., \& Zhang, S-D. (2019). Marine Proteobacteria as a source of natural products: advances in molecular tools and strategies. Natural Product Reports, 36, 1333-1350. https://doi.org/10.1039/c9np00020h

\section{General rights}

Copyright and moral rights for the publications made accessible in the public portal are retained by the authors and/or other copyright owners and it is a condition of accessing publications that users recognise and abide by the legal requirements associated with these rights.

- Users may download and print one copy of any publication from the public portal for the purpose of private study or research.

- You may not further distribute the material or use it for any profit-making activity or commercial gain

- You may freely distribute the URL identifying the publication in the public portal 


\title{
Marine Proteobacteria as a source of natural products:
}

\section{Advances in molecular tools and strategies}

Yannick Buijs, Pernille Kjersgaard Bech, Dario Vazquez-Albacete, Mikkel Bentzon-Tilia, Eva C. Sonnenschein, Lone Gram and Sheng-Da Zhang*

Department of Biotechnology and Biomedicine, Technical University of Denmark, Søltofts Plads bldg. 221, DK-2800 Kgs Lyngby

*Corresponding author: shez@dtu.dk

Covering: up to 2019

\begin{abstract}
Humanity is in dire need for novel medicinal compounds with biological activities ranging from antibiotic to anticancer and anti-dementia effects. Recent developments in genome sequencing and mining have revealed an unappreciated potential for bioactive molecule production in marine Proteobacteria. Also, novel bioactive compounds have been discovered through molecular manipulations of either the original marine host bacteria or in heterologous hosts. Nevertheless, in contrast to the large repertoire of such molecules as predicted by in silico analysis, few marine bioactive compounds have been reported. This review summarizes the recent advances in the study of natural products from marine Proteobacteria. Here we present successful examples on genetic engineering of biosynthetic gene clusters of natural products from marine Proteobacteria. We also discuss the future prospects of discovering novel bioactive molecules via both heterologous production methodology and the development of marine Proteobacteria as new cell factories.
\end{abstract}


1 INTRODUCTION

1.1 Bioactive compounds from marine Proteobacteria

2. GENETIC ENGINEERING OF NATURAL PRODUCT BGCS IN AND FROM MARINE PROTEOBACTERIA

2.1 Genetic engineering of BGCs in the native producers

2.1.1 Natural transformation in marine Proteobacteria

2.1.2 Chemical transformation in marine Proteobacteria

2.1.3 Electroporation in marine Proteobacteria

2.1.4 Conjugation in marine Proteobacteria

2.1.5 CRIPSR-Cas9 in marine Proteobacteria

2.2 Heterologous expression of BGCs from marine Proteobacteria

2.2.1 Heterologous expression of BGCs from cultivable marine Proteobacteria

2.2.2 Expression of BGCs from uncultivable marine Proteobacteria

3 MARINE PROTEOBACTERIA AS CELL FACTORIES

3.1 Marine Proteobacterial cell factory platforms

3.1.1 Vibrio natriegens as the new powerhouse

3.1.2 An upcoming evident marine Proteobacteria expression host:

Pseudoalteromonas

3.1.3 Other future marine cell factories

3.2 Marine Proteobacteria in industrial biotech production

4 CONCLUSION

5 CONFLICTS OF INTEREST

6 ACKNOWLEDGEMENTS

7 REFERENCES 


\section{INTRODUCTION}

Humanity is in dire need for novel medicinal compounds with biological activities ranging from antibiotic to anticancer and anti-dementia effects. Infectious diseases that were easily cured by antibiotics have recently become challenging due to the rapid development and spread of antibiotic resistance in infectious microorganisms. Diseases that mostly occur in the elderly (dementia, cancer, arthritis) are increasing with the aging population and we are still lacking adequate treatments. Natural products from plants and microorganisms have been a significant source of medicinal compounds and almost two thirds of our antibiotics are produced by or derived from microorganisms. ${ }^{1}$ Until recently, terrestrial microorganisms, especially Gram-positive Actinobacteria, have provided the majority of these bioactive compounds. However, our need for novel compounds has led to bioprospecting of microorganisms from hitherto unexplored or less explored environments, such as marine systems ${ }^{2}$ and also to new strategies for biodiscovery, e.g. genome mining, ${ }^{3}$ heterologous expression from metagenomes ${ }^{4}$ and using synthetic biology. ${ }^{5}$

Covering more than two thirds of the Earth's surface, the oceans harbor many different marine-specific habitats that are defined by a broad range of temperature or hydrostatic pressure, fluctuations in salinity, eukaryotic predation or viral attacks. ${ }^{6}$ These unique ecological parameters drive the adaptation of marine organisms including their production of marine-specific molecular compounds. ${ }^{6,7}$ Bioactive medicinal compounds have been isolated from a range of marine organisms, including marine sponges, tunicates, bryozoans, and microorganisms. ${ }^{8-10}$

It was anticipated that like on land, the Gram-positive Actinobacteria would be a prolific source of novel compounds and indeed many new promising compounds have been isolated from marine Actinobacteria. ${ }^{11}$ A prime example is the discovery of the anti-cancer agent salinosporamide A produced by the obligate marine bacterium Salinispora. ${ }^{12}$ Also, marine Cyanobacteria have provided many novel compounds such as curacin A, barbamide or the jamaicamides. ${ }^{13-15}$ However, it has also become evident that other marine Gram-negative bacteria are a rich source of secondary metabolites. ${ }^{16-19}$ For instance, more than 20 biosynthetic gene clusters (BGCs) can be found in a single genome of pigmented Pseudoalteromonas strains, which dedicate up to $15 \%$ of their genomes to production of secondary metabolites. ${ }^{20}$

In general, mining genomes revealed a large number of BGCs likely encoding bioactive compounds. ${ }^{17}$ However, due to the in vitro conditions during culturing in the laboratory, many BGCs are likely cryptic and their products cannot be easily detected. This untapped potential can be unlocked by enhancing production in the native organisms, first addressing cultivation issues (carbon source, co-cultivation with other bacteria) and also by metabolic engineering, or using heterologous expression in robust, established cell factories.

Molecular manipulation in marine bacteria is challenging due to the lack of wellestablished universal methods for genetic modification, and, for instance the requirement for salts during growth can be a challenge for electroporation. Fortunately, both electroporation and conjugation strategies applicable in marine bacteria are being developed. ${ }^{21-23}$ Single gene products from marine Proteobacteria have since the early eighties been cloned and expressed 
in heterologous hosts. ${ }^{24}$ However, transferring and heterologous expression of larger, more complex biosynthetic pathways is challenging in part because of the size (10-100 kbp) in part because of nuances in regulatory elements or metabolic background between the native producers and the engineering expression hosts. ${ }^{25}$ There are only very few successful examples, including cloning and expressing of alterobromide lipopeptides from Pseudoalteromonas piscicida in Escherichia coli. ${ }^{5,26,27}$

A prerequisite for successful cell engineering is identifying relevant genes and gene clusters, as well as the sequential enzymatic steps in the biosynthesis of the target compound. This can be facilitated by knocking out/in genes in the native producers, hence - again being able to molecularly manipulate the native producers is essential. The present paper outlines options and challenges in genetic editing of marine Proteobacteria as well as (the few) examples of heterologous expression of larger gene clusters and individual enzymes of the biosynthetic pathways involved in secondary metabolism. Finally, recent advances in employing marine Proteobacteria as chassis for synthetic biology and biotechnological production of bioactive compounds are outlined and a perspective on future potential cell factories is provided.

\subsection{Bioactive compounds from marine Proteobacteria}

Many bioactive compounds, notably antibiotics, have been isolated from Gram-positive Actinobacteria or filamentous fungi and Gram-negative bacteria have not been researched as extensively. However, recently genome mining has demonstrated that also Gram-negative bacteria of the phylum Proteobacteria harbor biosynthetic gene clusters likely encoding bioactive compounds.

Proteobacteria is the major phylum of Gram-negative bacteria and includes many wellknown pathogens from Vibrionaceae, Enterobacteriaceae and Pseudomonadaceae. Although Proteobacteria is the most abundant phylum in marine pelagic systems, ${ }^{28}$ only relatively few bioactive compounds have been isolated from this group of organisms. Most of these molecules, however, are not unique to the marine environment, and are also produced by terrestrial bacteria, algae, plants, or animals (Table 1). This is probably due to the horizontal gene transfer (HGT)-mediated spread of BGCs. ${ }^{3}$ For example, the dithiolopyrrolone group antibiotic, holomycin (1) (Table 1, Figure 1), initially isolated from cultures of the terrestrial Gram-positive bacteria Streptomyces griseus, ${ }^{29}$ Streptomyces sp. P6621 $1^{30}$ and Streptomyces clavuligerus, ${ }^{31}$ was recently extracted from cultures of Yersinia ruckeri ${ }^{32}$ and Photobacterium galatheae S2753. ${ }^{17,33}$ Comparison of the corresponding holomycin (1) BGCs of each strain reveals highly conserved core genes, ${ }^{32,34,35}$ and host specific genes involved in the holomycin (1) detoxification processes. ${ }^{32,35-37}$ This finding suggests that both HGT and host adaptation occurred during the evolution of holomycin (1) BGCs. Recently, along with the increasing number of genome sequences, novel BGCs have been uncovered in marine Proteobacteria and are being investigated. ${ }^{17,19,38-41}$ Despite this promising potential, genetic manipulations of these BGCs either in their native producers or in heterologous expression hosts are still challenging in the laboratory. An overview of selected marine Proteobacteria bioactive compounds, their native producers, the corresponding BGCs and their manipulation are summarized in Table 1 and discussed in the following sections. 
Table 1 A selection of representative bioactive compounds isolated from marine Proteobacteria

\begin{tabular}{|c|c|c|c|c|c|}
\hline Compounds & Bioactivity & $\begin{array}{l}\text { Marine proteobacterial } \\
\text { producers }\end{array}$ & Other producers & $\begin{array}{l}\text { Biosynthetic } \\
\text { gene cluster } \\
\text { and its size }\end{array}$ & Bioengineering manipulations \\
\hline $\begin{array}{l}\text { Astaxanthin } \\
44\end{array}$ & $\begin{array}{l}\text { Food colorant; } \\
\text { Dietary } \\
\text { supplement; feed } \\
\text { supplement }\end{array}$ & $\begin{array}{l}\text { Paracoccus haeundaensis; } \\
\text { Erythrobacter longus; } \\
\text { Haematococcus pluvialis }\end{array}$ & $\begin{array}{l}\text { Algae, shrimp, crab, } \\
\text { fishes, bacteria etc. }\end{array}$ & $\begin{array}{l}\operatorname{crtWZYIBE:} \\
\sim 11 \mathrm{~kb}\end{array}$ & $\begin{array}{l}\text { Random chemical mutagenesis; } \\
\text { Cloning entire BGC and } \\
\text { overexpression in native strain; } \\
\text { Heterologous expression in } \\
\text { Rhodovulum sulfidophilum }\end{array}$ \\
\hline $\begin{array}{l}\text { Bromoaltero- } \\
\text { chromide } \\
(7 \mathbf{b})^{45}\end{array}$ & $\begin{array}{l}\text { Antibiotic } \\
\text { activity }\end{array}$ & Pseudoalteromonas species & - & $\begin{array}{l}\text { bmp cluster } \\
\text { and PPTase: } \\
\sim 34 \mathrm{~kb}\end{array}$ & $\begin{array}{l}\text { Heterologous expression and } \\
\text { biosynthetic pathway } \\
\text { characterized in E. coli }\end{array}$ \\
\hline $\begin{array}{l}\text { Bryostatins } \\
(\mathbf{1 0})^{10,46}\end{array}$ & $\begin{array}{l}\text { Cytotoxic } \\
\text { activity against } \\
\text { carcinomas; } \\
\text { Anti-Alzheimer's } \\
\text { potential }\end{array}$ & $\begin{array}{l}\text { Candidatus Endobugula } \\
\text { sertula (uncultured) }\end{array}$ & - & $\begin{array}{l}\text { bry cluster: } \\
65-77 \mathrm{~kb}\end{array}$ & Metagenomics cosmid libraries. \\
\hline${ }_{51}^{\text {Ectoine }(\mathbf{5})^{47-}}$ & $\begin{array}{l}\text { Maintain osmotic } \\
\text { balance; superior } \\
\text { moisturizer; anti- } \\
\text { aging; against } \\
\text { lung } \\
\text { inflammation }\end{array}$ & $\begin{array}{l}\text { Halomonas elongate; } \\
\text { Halomonas titanicae; } \\
\text { Halomonas ventosae; } \\
\text { Halorhodospira halophile. }\end{array}$ & $\begin{array}{l}\text { Brevibacterium } \\
\text { linens; } \\
\text { Marinococcus } \\
\text { halophilus; } \\
\text { Pseudomonas } \\
\text { stutzeri; }\end{array}$ & $\begin{array}{l}\text { ect } \text { cluster: } \\
3.5-4.5 \mathrm{~kb}\end{array}$ & Knockouts and overexpression. \\
\hline
\end{tabular}




\begin{tabular}{|c|c|c|c|c|c|}
\hline $\begin{array}{l}\text { Haliangicin } \\
(9)^{52}\end{array}$ & $\begin{array}{l}\text { Antifungal } \\
\text { antibiotic }\end{array}$ & Haliangium ochraceum & - & $\begin{array}{l}\text { hli cluster: } \\
47.8 \mathrm{~kb}\end{array}$ & $\begin{array}{l}\text { Heterologous expression in } \\
\text { Myxobacteria xanthus }\end{array}$ \\
\hline $\begin{array}{l}\text { Holomycin } \\
\text { (1) }\end{array}$ & $\begin{array}{l}\text { Antibiotic } \\
\text { activity; anti- } \\
\text { cancer }\end{array}$ & Photobaceterium galatheae; & $\begin{array}{l}\text { Streptomyces spp. } \\
\text { Yersinia ruckeri; }\end{array}$ & $\begin{array}{l}\text { hlm cluster or } \\
\text { hom cluster: } \\
\sim 11 \mathrm{~kb}\end{array}$ & Knockouts and knockins \\
\hline $\begin{array}{l}\text { Pentabromo- } \\
\text { pseudilin }(6)^{54}\end{array}$ & $\begin{array}{l}\text { Antibiotic } \\
\text { activity }\end{array}$ & $\begin{array}{l}\text { Pseudomonas bromoutilis; } \\
\text { Pa. luteoviolacea }\end{array}$ & - & $\begin{array}{l}\text { bmp cluster: } \\
\sim 12.5 \mathrm{~kb}\end{array}$ & $\begin{array}{l}\text { Heterologous expression in } E \text {. } \\
\text { coli }\end{array}$ \\
\hline $\begin{array}{l}\text { Poly-3- } \\
\text { hydroxy- } \\
\text { butyrate } \\
(\text { PHB })^{55-57}\end{array}$ & $\begin{array}{l}\text { Bioplastics; } \\
\text { Biomedical } \\
\text { applications }\end{array}$ & Halomonas spp. & $\begin{array}{l}\text { Cupriavidus } \\
\text { necator; Bacillus } \\
\text { megaterium; } \\
\text { Methylobacterium } \\
\text { rhodesianum; etc. }\end{array}$ & $\begin{array}{l}\text { phb gene } \\
\text { cluster } \\
\sim 3.5 \mathrm{~kb}\end{array}$ & Knockouts and overexpression \\
\hline $\begin{array}{l}\text { Prodigiosin } \\
(4)^{58,59}\end{array}$ & $\begin{array}{l}\text { Red pigments; } \\
\text { anti-cancer }\end{array}$ & Pseudoalteromonas strains & $\begin{array}{l}\text { Serratia } \\
\text { marcescens; } \\
\text { Bacillus prodigiosus }\end{array}$ & $\begin{array}{l}\text { cueR/pigA-N- } \\
\text { copA: } \sim 25 \mathrm{~kb}\end{array}$ & Knockouts and expression \\
\hline $\begin{array}{l}\text { Solonamide } \\
(\mathbf{1 1})^{16,60,61}\end{array}$ & $\begin{array}{l}\text { Antivirulence of } \\
\text { MRSA }\end{array}$ & Pa. galatheae & - & - & - \\
\hline $\begin{array}{l}\text { Thiomarinol } \\
(3)^{62}\end{array}$ & $\begin{array}{l}\text { Antibiotic } \\
\text { activity }\end{array}$ & $\begin{array}{l}\text { Pseudoalteromonas SANK } \\
73390\end{array}$ & - & $\begin{array}{l}\text { Plasmid } \\
\text { pTML1: } \\
\sim 87 \mathrm{~kb}\end{array}$ & Knockouts \\
\hline
\end{tabular}




\begin{tabular}{|c|c|c|c|c|c|}
\hline $\begin{array}{l}\text { Tropodithietic } \\
\text { acid, TDA } \\
(\mathbf{2})^{63-65}\end{array}$ & $\begin{array}{l}\text { Antibiotic } \\
\text { activity }\end{array}$ & $\begin{array}{l}\text { Phaeobacter; Roseobacter } \\
\text { spp. }\end{array}$ & - & $\begin{array}{l}\text { paa and } t d a \\
\text { cluster: } \\
\sim 12.3 \mathrm{~kb}\end{array}$ & $\begin{array}{l}\text { Random transposon insertion } \\
\text { mutagenesis }\end{array}$ \\
\hline Vibriobactin ${ }^{66}$ & $\begin{array}{l}\text { Siderophore; iron } \\
\text { chelator }\end{array}$ & Vibrio cholerae & - & $\begin{array}{l}\text { vib-vie } \\
\text { cluster: } \\
\sim 12 \mathrm{~kb}\end{array}$ & Expression in native strain \\
\hline $\begin{array}{l}\text { Violacein } \\
(\mathbf{8})^{67,68}\end{array}$ & $\begin{array}{l}\text { Pigment; } \\
\text { antibiotic } \\
\text { activity; anti- } \\
\text { cancer }\end{array}$ & Pseudoalteromonas species & $\begin{array}{l}\text { Chromobacterium vi } \\
\text { olaceum; } \\
\text { Collimonas sp.; } \\
\text { Duganella } \text { spp.; } \\
\text { Janthinobacterium } \\
\text { spp. } \\
\text { Microbulbifer spp; } \\
\text { etc. }\end{array}$ & $\begin{array}{l}\text { vioABCDE: } \\
\sim 8 \mathrm{~kb}\end{array}$ & $\begin{array}{l}\text { Heterologous expression and } \\
\text { biosynthetic pathway } \\
\text { characterized in various hosts }\end{array}$ \\
\hline
\end{tabular}




\section{GENETIC ENGINEERING OF BIOSYNTHETIC GENE CLUSTERS IN AND FROM MARINE PROTEOBACTERIA}

\subsection{Genetic engineering of BGCs in the native producers}

Molecular engineering of natural product-producing microorganisms has become possible with the recent breakthroughs in genome sequencing and functional genomics. ${ }^{17,69-71}$ There are several advantages in developing such genetic manipulation tools. First, gene-targeting mutagenesis could link orphan BGCs to identified bioactive compounds, ${ }^{72,73}$ which is the foundation and prerequisite for refactoring BGCs in either the native producers or the surrogate hosts. In addition, the native producers encode all structural genes and regulatory elements for the expression of BGCs, such as promoters, genetic regulators, and host cell self-protection genes. ${ }^{37,68,74}$ Therefore, genetic manipulation in the native producer cells is essential to reveal the regulatory mechanism of BGC expression. This not only holds the potential to increase the yield of bioactive molecules, ${ }^{68}$ but also, more importantly, reveals the physiological (and ecological) functions of these molecules. ${ }^{75,76}$ Genetic tools can also be used to activate presumed silent BGCs, facilitating the success rate of discovering more bioactive molecules in the native hosts. ${ }^{77}$ In the following sections, we discuss the state-ofthe-art of genetic manipulation tools in marine Proteobacteria, with a focus on strains that harbor BGCs.

\subsubsection{Natural transformation of marine Proteobacteria}

Natural transformation has been widely used in marine Proteobacteria, especially the marine chitinolytic species of the Vibrionacaeae family. In 2005, Meibom et al. ${ }^{78}$ found that chitin induces natural competence in Vibrio cholerae. The molecular mechanism of chitin-induced competence was subsequently characterized in $V$. cholerae and several other Vibrio strains, such as $V$. parahaemolyticus,${ }^{79} \mathrm{~V}$. vulnificus,${ }^{80}$ and $V$. fischeri ${ }^{81}$ The form of chitin capable of inducing cell competence differs among species or even among strains. For example, competence of $V$. fischeri ${ }^{81}$ is only induced by oligosaccharidic chitin, whereas all forms of chitin induce competence in $V$. cholerae and $V$. vulnificus ${ }^{78,80}$ Chen et al. ${ }^{79}$ succeeded in generating a deletion mutant of $V$. parahaemolyticus $\mathrm{O} 3: \mathrm{K} 6$ with a chitin-induced natural transformation approach, while Chimalapati et al. ${ }^{23}$ could not induce natural transformation in V. parahaemolyticus CAB2 using the same approach. Instead, the authors overexpressed the $V$. cholerae gene tfo $X$, a natural transformation regulator, and thereby induced the natural competence in $V$. parahaemolyticus. ${ }^{23}$ Natural transformation is an efficient method for molecular manipulating of Vibrio species, however, it has seldom been used in genetic engineering of natural product BGCs in Vibrionaceae, mainly due to the fact that marine Proteobacteria have only recently been identified as a significant source of novel bioactive compounds. ${ }^{17,33,82}$

\subsubsection{Chemical transformation of marine Proteobacteria}

Successful transformations by chemical procedures have only rarely been reported for marine Proteobacteria. Marcus et al. ${ }^{83}$ used the osmotic shock protocol in an attempt to transform $V$. cholerae strains with the plasmid pBR322, however, without success. On the other hand, a similar procedure has been successfully applied in a DNase-negative mutant of $V$. cholerae, 
suggesting that extracellular DNase is one of the major barriers for applying chemical transformation in $V$. cholerae. Piekarski et al. ${ }^{21}$ also attempted to transform 12 strains from the Roseobacter group using standard chemical transformation procedures, but these proved to be unsuccessful. These results highlight that more efforts should be directed toward the investigation of the transformability of marine Proteobacteria. In 2016, Weinstock et al. ${ }^{84}$ deployed chemical transformation as well as electroporation to engineer the fast-growing marine species Virbio natriegens. As discussed in section 3, this species has been proposed as a competitive host for biotech applications, including the production of bioactive molecules from marine Proteobacteria.

\subsubsection{Electroporation in marine Proteobacteria}

Electroporation is a well-established method, which has worked well for a broad range of bacterial species, however, failures have also been reported. The efficiency of electroporation is strain-dependent, and affected by many factors, such as growth conditions, temperature, restriction enzyme systems, field strength and type of exogenous DNA. ${ }^{22,85,86}$ Strain specific optimization of these parameters is therefore normally required. Electroporation has been used for several marine Proteobacterial species of the Vibrio, Pseudoalteromonas, Roseobacter, Caulobacter and Halomonas genera. In 2018, Delavat et al. ${ }^{87}$ developed a rapid and efficient electroporation protocol for Vibrio and Pseudoalteromonas strains. However, electroporation was only successful in the stationary phase of $V$. harveyi cells grown at $37^{\circ} \mathrm{C}$, but not in cells grown at $28{ }^{\circ} \mathrm{C}$ or exponential phase cells grown at $37^{\circ} \mathrm{C}$. The same protocol was also successfully applied in V. campbellii BAA-1116, and in Pseudoalteromonas spp. MV21 and 3 J6.

The earliest example of the use of electroporation in marine Proteobacteria for secondary metabolite research is reported in 1997. ${ }^{66}$ Wyckoff et al. studied the genetics of the biosynthesis of vibriobactin, a siderophore produced by the pathogen $V$. cholerae. Siderophores are iron-scavenging compounds and are commonly produced by marine bacteria, due to typically low iron levels in the marine environment. ${ }^{88}$

Pre-dating the sequence revolution, Wyckoff and coworkers had to rely on classical methods such as library screening and complementation to identify the vibriobactin biosynthetic genes in $V$. cholerae. A set of well characterized $E$. coli mutants unable to produce enterobactin, a siderophore that is structurally similar to vibriobactin, were used in this study. Because the biosynthesis of enterobactin and vibriobactin share the same intermediate (2, 3-dihydroxybenzoic acid), the authors hypothesized that E. coli mutants unable to synthesize this molecule could be complemented by homologous genes from $V$. cholerae. A cosmid library of $V$. cholerae was screened for complementation of enterobactin biosynthesis, which led to the identification of the $v i b A B C D E$ gene cluster. ${ }^{66}$ To confirm the role of vibA in the biosynthesis of vibriobactin, the authors inactivated the vibA gene in $V$. cholerae. Transposon mutagenesis with the Tn5 transposon system was carried out in $E$. coli to obtain a plasmid carrying an inactivated vibA fragment, which was identified by loss of the ability to complement enterobactin biosynthesis. ${ }^{89}$ A suicide vector was constructed by subcloning the vibA::Tn5 fragment and the $s a c B$ gene into vector pAT153. V. cholerae was subsequently transformed by electroporation according to the protocol described by 
Henderson and Payne, ${ }^{90}$ and a vibriobactin negative mutant was obtained by allelic exchange of vibA with vibA::Tn5.

Another more recent example of using electroporation is found in the genetic study of tropodithietic acid (TDA) (2) (Table 1 and Figure 1) production by bacteria from the Roseobacter group. ${ }^{64}$ This compound has received a lot of interest due to its broad antibacterial activity, including its effect on fish and human pathogenic bacteria. ${ }^{91}$ Also, the TDA-producing Phaeobacter and Ruegeria strains occur naturally in aquaculture environments ${ }^{92}$ and several attempts to evolve TDA resistance have not resulted in TDA resistant mutants. ${ }^{93,94}$ For these reasons, natural TDA producers hold great promise as probiotic cultures in large-scale aquaculture industries. ${ }^{63,93}$

Genetic interrogation of the TDA (2) biosynthetic genes in the Alphaproteobacterial roseobacters was first reported by Geng et al. in 2008. ${ }^{64}$ Random transposon insertion mutagenesis in Silicibacter and Phaeobacter led to the finding that the $t d a$ genes reside on a previously unidentified $130 \mathrm{~kb}$ plasmid. Transfer of the commercially available EZ-Tn5 transposome into the cells was accomplished by electroporation, after preparation of electrocompetent cells as described by Miller and Belas. ${ }^{64,95}$ Kanamycin resistant transposon mutants were screened for loss of TDA (2) production by means of antibacterial assays:

Phaeobacter and Silicibacter mutants unable to inhibit $V$. anguillarum growth were identified as TDA negative.

\subsubsection{Conjugation in marine Proteobacteria}

A more common approach of transforming marine Proteobacteria is using bacterial conjugation. Conjugation is the most efficient method to genetically manipulate the BGCs in marine Proteobacteria that are recalcitrant to electroporation and chemical transformation methods. However, conjugation is a time-consuming procedure that also requires a step to counter-select the donor cells from the transconjugant cells. Several methods have, therefore, been developed to address this issue. One of the most efficient strategies is employing the $E$. coli auxotrophic strains, such as B2163 and WM3064. Another concern in conjugation is the efficiency of the counter-selectable markers for allelic exchange.

Recently, Luo et al. ${ }^{96}$ developed an efficient system for gene deletion in Vibrio spp. by constructing the suicide plasmids pLP11 and pLP12 (derived from the plasmid pSW23T), which carry the chloramphenicol antibiotic resistant gene and a toxin gene, vmi480, as the counter-selectable marker. The authors obtained knockout mutants by using E. coli B2163 as the donor. This conjugation-based genetic tool was successfully used in several Vibrio species including $V$. cholerae, $V$. vulnificus, $V$. parahaemolyticus, and Vibrio alginolyticus. Consequently, vmi480 is considered an effective counter-selectable gene for Vibrio.

The well-known $s a c B$ counter-selection system (pDM-derived plasmids) has also been widely used in marine Proteobacteria. Although in Vibrio strains the toxicity of sucrose-SacB is affected by saline media, many Pseudoalteromonas strains are susceptible to the toxicity of SacB. ${ }^{59}$ In short, the combination of auxotrophic donor strains and effective counter-selection markers makes conjugation a reliable technique for engineering BGCs in marine Proteobacteria. 
Investigation of the genetics of thiomarinol (3) (Table 1 and Figure 1) production by the Gammaproteobacterium Pseudoalteromonas SANK 73390 is also relevant. ${ }^{62}$ Three separate gene knockouts were constructed by using the suicide vector pAKE604, which contains the $s a c B$ gene for counterselection to facilitate allelic exchange. ${ }^{97}$ Transfer of the conjugational plasmid was accomplished via the donor strain E. coli S17-1. This work demonstrated that two distinct biosynthetic pathways are responsible for thiomarinol (3) production in Pseudoalteromonas SANK 73390, each of them synthesizing its own moiety. Mupirocin, a polyketide antibiotic produced by Pseudomonas fluorescens, and holomycin (1), a pyrrothine antibiotic first discovered from $S$. clavuligerus are both produced and joined together to form thiomarinol (3) in this Pseudoalteromonas strain. Furthermore, the authors discovered that all the biosynthetic genes reside on a $97 \mathrm{~kb}$ plasmid. These results raise interesting questions concerning the evolution and acquisition of the clusters and the role that HGT events have played herein. However, the authors reported a high degree of sequence divergence between the mupirocin biosynthetic genes found in P. fluorescens and their homologues in Pseudoalteromonas SANK $73390 .{ }^{62}$

Other studies have explored and developed genetic tools for Pseudoalteromonas engineering. ${ }^{59}$ A gene knockout protocol was established by cloning homologous fragments upstream and downstream of the target gene in the pK18mobsacB-based suicide vector. ${ }^{98}$ Conjugational transfer of the plasmid was accomplished via the E. coli WM3064 strain, which is auxotrophic for diaminopimelic acid (DAP), facilitating an easy way to counter select the donor cells from transconjugant cells. Two homologous recombination crossover events then ultimately lead to either the wild type genotype or the desired knock out mutant. Using this system, a knockout of the pigM-K genes was confirmed by the lack of production of the red pigment prodigiosin (4) (Table 1, Figure 1), thus showing the feasibility of the method. ${ }^{59}$ Importantly, the authors demonstrated the compatibility of this system in nine Pseudoalteromonas strains from at least six differently classified species.

Conjugational transfer of DNA is more versatile than solely constructing gene knockout mutants. An example is the metabolic engineering of the Alphaproteobacterium Paracoccus for improved production of the secondary metabolite astaxanthin. ${ }^{44}$ The native BGC responsible for astaxanthin production was cloned into the broad-host-range expression vector pBBR1-MCS2. ${ }^{99}$ The authors subsequently transformed the recombinant plasmid into Paracoccus by mating with donor E. coli S17-1. In this case, conjugative broad-host-range plasmid was used to increase the copy number of BGC in the native Paracoccus strain. Overexpression of a gene was also accomplished in the halophilic Gammaproteobacterium Halomonas elongata. Tanimura et al. overexpressed the lys $C$ gene (encoding aspartate kinase) in order to improve production of ectoine (5). In this case, the broad-host expression vector pHS15N was used and conjugation was achieved by E. coli HB101 carrying the mobilization helper plasmid pRK2013. ${ }^{100}$

Finally, we highlight a case, which combines conjugation with other genetic engineering tools. Fu et al. genetically manipulated a Halomonas strain to improve production of the storage polymer and bioplastic poly-3-hydroxybutyrate (PHB). ${ }^{55}$ To this end, a markerless knock out strategy was developed based on the rare I-SceI restriction site. ${ }^{101}$ Six I-SceI 
restriction sites were cloned into the suicide vector $\mathrm{pRE} 112$, and the resulting plasmid was introduced into Halomonas TD01 by conjugation using E. coli S17-1. Chromosomal integration of the suicide vector by homologous recombination was achieved under selective pressure of chloramphenicol resistance. Subsequently, a second plasmid based on the broadhost-range vector pBBR1-MCS1 was introduced in order to express the I-SceI endonuclease. In vivo digestion by I-SceI endonuclease would result in lethal double strand breaks, providing the selective pressure for a second homologous crossover event and deletion of the gene target. Although the selective pressure by lethal restriction may increase transformation efficiency compared to conventional counter-selection genes, the use of an I-SceI endonuclease expression vector necessitates a second time-costly conjugation step.

\subsubsection{CRISPR-Cas9 systems in marine Proteobacteria}

More recently, Tao et al from the same group reported the use of the CRISPRi system ${ }^{102}$ for controlled transcriptional repression in the same strain. ${ }^{56}$ This tool makes use of a catalytically dead Cas9 protein (dCas9), which is lead to a target sequence by a designed small guide RNA (sgRNA). Instead of making a double strand cut, dCas9 is able to suppress gene transcription, presumably by sterically blocking RNA polymerase. Tao et al. constructed the conjugational plasmid pli-dCas9-sgRNA and used this as vector for the introduction of sgRNA sequences into Halomonas TD01. ${ }^{56}$ The IPTG-inducible $\mathrm{P}_{\text {trc }}$ promoter was used for the transcription of the sgRNA and the dCas9 protein. After conjugation with E. coli S17-1, the expression of $\operatorname{prpC}$ (2-methylcitrate synthase) was reduced by adding IPTG into the culture of Halomonas conjugants carring pli-dCas9-sgRNA plasmid. This resulted in a higher content of 3-hydroxyvalerate in the poly-3-hydroxybutyrate-co-3-hydroxyvalerate (PHBV) polymer. ${ }^{56}$ In parallel, Yin et al. ${ }^{103}$ developed a conjugative plasmid carrying the CRISPRi system $^{102}$ to circumvent the issue of a counter-selective marker. The CRISPRi system was successfully transferred into marine vibrio strain Vibrio fluvialis QY27 by the donor E. coli WM3064 and the expression of trimethylamine N-oxide (TMAO) reductase gene was knocked down in QY27.

\subsection{Heterologous expression of BGCs from marine Proteobacteria}

A large number of marine proteobacterial enzymes have been cloned and expressed in different bacterial expression systems and have a broad potential in industrial applications. ${ }^{104}$ Cold-active enzymes, such as the $\alpha$-amylase from the Antarctic psychrophile, Alteromonas haloplanctis has been studied extensively with applications in baking, textile and detergent industries. ${ }^{105}$ Recently, fucoidanases from marine Proteobacteria that are able to degrade brown algae have gained increasingly attention due to the beneficial biomedical properties of fucoidan derived oligosaccharides. ${ }^{106,107}$

Heterologous expression has been a powerful tool to identify novel gene functions, but it becomes more cumbersome when gene fragments exceed $10 \mathrm{~kb} .{ }^{25}$ However, most biosynthetic pathways involve dozens of proteins that catalyze and regulate the production of secondary metabolites and thus are often larger than $10 \mathrm{~kb}$ and some may even exceed 100 $\mathrm{kb}$. Yet, a number of BGCs, mainly encoding natural products from Actinomycetes, ${ }^{108}$ have been cloned and expressed using different bacterial expression systems, while very few examples have been reported for BGCs of the marine Proteobacteria derived natural products. 


\subsubsection{Heterologous expression of BGCs from cultivable marine Proteobacteria}

Many marine natural products are halogenated, reflecting the availability of chloride and bromide ions in seawater. Thus, marine organisms including the Proteobacteria have developed a range of halogen-acting enzymes that activate and transfer chloride and bromide to organic molecules. Interestingly, organobromines are the most commonly found halogenated natural products produced by marine organisms, even though the concentration of the bromide anion is lower than that of chlorine. ${ }^{109}$ Pentabromopseudilin (6) (Table 1, Figure 1) produced by the marine Gammaproteobacterium Pseudomonas bromoutilis ${ }^{110}$ was the first marine antibiotic to be discovered in 1966. Since then, several polybrominated aromatic organic compounds have been isolated from marine Proteobacteria. ${ }^{111,112}$ Agarwal et al. ${ }^{113}$ reconstructed in vitro all the enzymatic steps in the marine brominated pyrroles/phenols biosynthesis from $P$. luteoviolacae and P. phenolica and furthermore identified two novel flavin-dependent brominases. The entire BGC $(\sim 12.5 \mathrm{~kb})$ responsible for the production of the widespread polybrominated compounds (Figure 2) was expressed in E. coli using transformation-associated recombination (TAR).

The TAR strategy ${ }^{114}$ enables specific capture of target biosynthetic pathways, avoiding the typical size limitations of traditionally used cloning techniques such as Gibson assembly and USER-cloning. With this technique, large fragments of DNA (up to $100 \mathrm{~kb}$ ) are captured without the need for intermediate PCR steps using homologous recombination in yeast (Saccharomyces cerevisae) and subsequently transferred to and expressed in E. coli. ${ }^{113}$ Thus, cloning of large DNA fragments has become more affordable.

A great advantage of heterologous expression is that it reduces the need to develop new genetic tools for the manipulation of each genus or species of interest. Heterologous expression of enzymes has been performed in E. coli, Bacillus subtilis, Streptomyces, lactic acid bacteria, yeast and filamentous fungi for decades. Due to the well-characterized genome of $E$. coli, the variety of genetic tools available and its taxonomic relation to marine Proteobacteria, this organism is a good candidate for recombinant production of marine Proteobacteria derived natural products. In addition, E. coli is able to grow rapidly to high densities on inexpensive substrates and there are an increasing number of cloning vectors and mutant strains. ${ }^{115}$

The antibacterial and cytotoxic lipopeptides, alterochromides (7) (Figure 1) are produced by multiple species of the marine genus Pseudoalteromonas, including P. piscicida that can synthetize alterochromides (7) with bromination of the lipid moiety. ${ }^{45,116}$ Again, the TAR strategy was used to capture the $\sim 34 \mathrm{~kb}$ pathway for production of the bromoalterochromide (7b) (Table 1, Figure 1), of which the biosynthetic pathway included a non-ribosomal peptide synthetase (NRPS), fatty acid synthase (FAS), flavin-dependent halogenase and transporter proteins. ${ }^{26}$ Furthermore, to compensate for the lack of specific thiolation machinery in E. coli, a recombinant PPTase from the related Gammaproteobacterium P. luteoviolacea was used. ${ }^{26,117}$ By this, the full alterochromide biosynthetic pathway was constructed and confirmed to be functional in E. coli. However, the production titer was 60 -fold lower than that of one of the native producers. Further replacement of the native promoter with the inducible T7-promoter improved the yield of bromoalterochromide A (7b) by 20 -fold. 
The trend of using either native or T7 promoters to achieve substantial expression of large gene clusters extends to BGCs of other compounds. ${ }^{27,118,119}$ In some cases, production titers using T7-driven expression in E. coli are lower than those from the native producers despite the closer phylogenetic relationship of E. coli and marine Gammaproteobacteria. One reason could be that the production of natural products involves specific chaperones or other posttranslational maturations of the synthetic enzymes which are not encoded within the BGC or the $E$. coli host. Additionally, lowering the temperature can improve the folding of the recombinant proteins from some BGCs. ${ }^{68}$

Zhang et al. ${ }^{68}$ challenged the reasoning that $E$. coli should be the obvious candidate for recombinant expression of marine Proteobacteria-derived natural products. One broad-hostrange expression vector was constructed in order to validate the recombinant production titer of the antibacterial pigment violacein (8) (vio2ta16; Table 1, Figure 1) from P. luteoviolacea 2 ta16 in three Proteobacterial hosts, the Alphaproteobacterium Agrobacterium tumefaciens and two Gammaproteobacteria, Pseudomonas putida and E. coli. Both A. tumefaciens and $P$. putida are isolated from soil; and the former one is often used for plant transformation. $P$. putida is a metabolically versatile and biosafety-certified host that is often used for heterologous expression. ${ }^{120}$ Some $P$. putida strains possess a phosphopantetheinyl transferase that post-translationally activates the carrier protein $(\mathrm{CP})$ domains of various polyketide synthases (PKSs), NRPs and FASs, which are required for heterologous expression of CPutilizing BGCs from myxobacteria and Streptomyces. ${ }^{121}$ Despite that both E. coli and $P$. luteoviolacea belong to the Gammaproteobacteria, little or no production was observed in $E$. coli host strains. However, violacein $(\mathbf{8})$ production was readily detectable from both $A$. tumefaciens and P. putida.

Regulatory elements, such as the LuxR-type regulators are often located within the BGCs or just outside the clusters. ${ }^{122}$ If the native promoter is to be included in the recombinant BGC, and the transcription factor that activates the promoter is not captured or co-expressed along with the target BGC, production cannot be achieved in the expression host. In order to understand why the vio2tal6 native promoter was recognized by A. tumefaciens and P. putida and not $E$. coli, Zhang et al. ${ }^{68}$ identified transcriptional factors in the two foreign expression hosts which are homologous to the Pvi regulator (PviR) found in P. luteoviolacea 2 ta16. Even though E. coli harbors PviR homologs with significant sequence similarity, none of the regulators were able to increase violacein $(8)$ production when overexpressed. This study suggests that neither similar phylogeny of the host organism nor the presence of homologous individual protein components are directly predictive with the capability to express the target BGC. Instead, one may consider the distribution of homologous BGCs as well. An example is the regulator PviR, which is conserved among all Pseudoalteromonas that harbor the antibacterial pigment violacein (8) and thus it is possible to develop Pseudoalteromonas hosts that contain the full regulatory machinery for activation of the BGC. ${ }^{68}$

Myxobacteria are a group of Deltaproteobacteria, which commonly produce antifungal compounds such as myxothiazols that inhibit the mitochondrial electron transport chain. ${ }^{123}$ They also produce metabolites with antibacterial activity including several RNA polymerase inhibitors such as corallopyronin, etnangien, myxopyronin or pipostatin. ${ }^{123}$ Marine 
myxobacteria have emerged as one of the richest sources in terms of secondary metabolites. ${ }^{40,124}$ Haliangicin (9) (Table 1, Figure 1) is naturally produced by the Haiangium ochaceum SMP-2, a slow-growing marine myxobacterium, which is difficult to manipulate genetically. Structural analysis of the haliangicin (9) backbone suggested a biosynthetic pathway purely composed by PKs. ${ }^{52}$ Several modification genes are essential for its biosynthesis. Thanks to the analysis of haliangicin precursors using ${ }^{13} \mathrm{C}$-labelled substrates, it was possible to determine the biosynthetic pathway. The authors reconstructed the pathway from a cosmid library using $\lambda$-Red recombineering and integrated it into the Myxococcos xanthus genome. The engineered strain was capable of producing 10 -fold higher amounts of haliangicin than the wild-type $H$. ochaceum. ${ }^{52}$

As new cloning tools become available and the repertoire of expression hosts expands, ${ }^{25}$ heterologous expression offers a promising alternative to unravel new natural products from the cryptic or "silent" BGCs of marine Proteobacteria.

\subsubsection{Expression of BGCs from uncultivable marine Proteobacteria}

For decades, microbiologists have recognized the fact that the vast majority of environmental microbes are recalcitrant to cultivation. ${ }^{125}$ Deep amplicon sequencing analyses suggest substantial biosynthetic potential of the uncultivable bacteria, and even frequently sampled microbial communities, such as those present in soil, give a diverse collection of novel genes involved in the biosynthesis of potential natural products such as NRPs and PKs. ${ }^{126,127}$ As a substantial fraction of this biosynthetic potential likely lies beyond the reach of conventional culture-based approaches to natural product discovery, ${ }^{128,129}$ cultivation-independent strategies, i.e. mining of environmental DNA (eDNA), are necessary in order to exploit this resource. Through rigorous efforts to construct and screen cosmid libraries containing environmental DNA from soil, and subsequent heterologous expression of candidate clusters, such metagenomics-based approaches have led to the recovery of an array of interesting bioactive natural productss including violacein (8), ${ }^{130}$ turbomycine, ${ }^{131}$ and the malacidins. ${ }^{129}$

Metagenomic data suggest that Proteobacteria comprise more than half of the marine pelagic microbial communities. ${ }^{28}$ Considering the biosynthetic potential of cultivable representatives of this phylum, marine metagenomes are likely a trove of potential novel proteobacterial natural products and comparisons of chemoinformatic data has shown that $>70 \%$ of molecular scaffolds in the Dictionary of Marine Natural Products are unique for marine organisms. ${ }^{132 a, b}$

Mining marine metagenomes through sequence-based screening of cosmid libraries containing marine eDNA have revealed that bioactive compounds initially believed to be produced by marine animals and algae are in fact, in some cases, bacterial metabolites produced by the associated microbiome. ${ }^{133,134}$ Furthermore, such efforts have aided in the elucidation of the biosynthetic pathways of bioactive metabolites from marine Proteobacteria. One example is the currently uncultivable marine Gammaproteobacterium 'Candidatus Endobugula sertula', which is responsible for the production of bryostatins (10) (Table 1, Figure 1). Bryostatins (10) comprise a group of bioactive type I PK compounds, some of which presented cytotoxic activity against carcinomas as well as anti-Alzheimer's potential. ${ }^{135}$ Initially, the bryozoan Bugula neritina was believed to be responsible for the 
synthesis of the compound. Mining metagenomes of $B$. neritina-associated microbiome ultimately proved that bryostatin is synthesized by an unusual modular polyketide synthase encoded by the $65 \mathrm{~kb}$ bry gene cluster in a proteobacterial symbiont. ${ }^{133,134}$ Similar metagenome mining approaches has led to the identification of biosynthetic pathways of several natural products in uncultivable marine Proteobacteria, ${ }^{135}$ however such BGCs have yet to be cloned and expressed in their entirety.

Expression of BGCs from uncultivable marine Proteobacteria is still in its infancy. Several challenges hamper the successful expression and subsequent functional screening of metagenomic libraries. In general, natural products like NRPs and PKs are notoriously difficult to obtain from metagenomes compared to ordinary hydrolytic enzymes.

Metagenomics-based approaches for mining such compounds have not yet proved to be as efficient as originally anticipated. ${ }^{128}$ This is due to the immense diversity and complexity of natural microbial communities. In addition, on average less than $2 \%$ of bacterial genomes are devoted to natural product biosynthesis. ${ }^{136}$ Hence, assembling and recovering entire natural product gene clusters demand a deep level of sequencing, which is currently not costeffective. ${ }^{128}$

Functional screening of cosmid and fosmid libraries limits redundant sequencing, yet such an approach is restricted by the dependence on successful heterologous expression of BGCs, which is limited by host compatibility and the significant size of most BGCs. Despite these obstacles, Schmidt et al. ${ }^{137}$ expressed the relatively small $(12.5 \mathrm{~kb})$ pat BGC from a cyanobacterial symbiont of the ascidian Lissoclinum patella in E. coli, resulting in the successful production of patellamide A and C. Hence, expression of BGCs from uncultivable marine bacteria represents a means of tapping into the vast biosynthesis potential of marine microbial communities. Despite the fact that entire BGCs from uncultivable marine Proteobacteria have yet to be expressed heterologously, improvements in DNA sequencing depth and continued development of appropriate marine cell factories will likely facilitate such findings within the near future.

\section{MARINE PROTEOBACTERIA AS CELL FACTORIES}

A major challenge of translating the vast chemical space of Nature into application is the development of efficient production systems to exploit these molecules at a commercial scale. Whilst some natural products have been synthesized chemically, ${ }^{138}$ biological production often offers the most feasible way to achieve a sustainable large-scale supply. As described in section 2.2, there are only a few examples of marine-derived natural products heterologously produced in the pioneering host organisms. Therefore, bacterial hosts other than these "old", well-studied workhorses are drawing attention as novel cell factories because of their metabolic diversity and biosynthetic potential. ${ }^{103,139,140}$ Expressing certain genes heterologously in the work horse of heterologous expression, E. coli, may result in poor recognition of regulatory sequences, misfolding of the translated product and low protein secretion. The latter is often due to an impaired recognition of the $E$. coli SRP/SECdependent pathway elements. Another detrimental effect in protein solubility is commonly experienced under mesophilic conditions, during heterologous expression in E. coli. ${ }^{141}$

\subsection{Marine Proteobacterial cell factory platforms}


Marine Proteobacteria harbour great potential as future cell factories. At the current state of knowledge, Proteobacteria represent by far the largest group in the pelagic ocean microbiome, representing $55 \%$ of all bacteria. ${ }^{28}$ Within the Proteobacteria phylum, the classes of Alpha-, Gamma-, Beta-, Delta- and Epsilonproteobacteria have been shown to comprise $32,13,2,2$, and $0.4 \%$ of all bacteria in the water column, respectively (Figure 3 ). From a different angle, bacteria of these classes might have become the dominant group in the ocean, because they have evolved diverse metabolic and biosynthetic strategies in order to adapt to the extremely diverse environments, which makes them attractive and reasonable candidates for new cell factories. Considering successful heterologous expression of natural products as a starting point for novel cell factories, current knowledge points to the following species having potential for future development.

\subsubsection{Vibrio natriegens as the new powerhouse}

The marine Gammaproteobacterium Vibrio natriegens (Figure 4), initially isolated from salt marshes, has been studied since $1960 .^{142}$ A distinctive feature of $V$. natriegens is its short doubling time and its high substrate uptake rates. ${ }^{143} \mathrm{~V}$. natriegens grows both on solid and liquid media faster than the commercial strain $E$. coli NEB Turbo, with generation times of 15 min vs $27 \mathrm{~min}$, respectively. ${ }^{84}$ This has sparked the interest of the synthetic biology community to develop future applications. Standard DNA transformation and conjugation protocols are available for $V$. natriegens with similar efficiencies as for E. coli. Expression vectors with $\mathrm{p} 15 \mathrm{~A}, \mathrm{pMB} 1$ and $\mathrm{pMB} 1$-derived origins of replication have been developed to facilitate heterologous expression, and four inducible promoters could be used in this strain: IPTG inducible lacUV5 and trc promoters, arabinose inducible araBAD promoter and the $\lambda$ phage $p \mathrm{R}$ promoter. ${ }^{84}$ Furthermore, Weinstock et al. ${ }^{84}$ attempted to improve the characteristics of $V$. natriegens for use in molecular biology by genomic reduction. A total of $192 \mathrm{~kb}$ of genomic DNA was removed, including nucleases and restriction-modification systems. Further developments of this strain, called Vmax, are pursued with the aim to commercialize this Vibrio as superior host for use in molecular biology. ${ }^{144}$

The laboratory of George Church recently developed recombineering techniques for multiplexed cell factory development in $V$. natriegens. ${ }^{145}$ The $\lambda$-Red homologs SXT-beta, SXT-Exo and $\lambda$-Gam present in $V$. natriegens achieve up to 10,000-fold higher recombination rates of single and double stranded DNA oligonucleotides. In parallel, Dalia et al. designed an engineering tool by exploiting natural transformation in $V$. natriegens. ${ }^{146}$ Multiplexed genome editing by natural transformation or MuGENT, as the method is called, facilitatates rapid and scarless genome editing. The technique is based on overexpression of $T f o X$, which renders $V$. natriegens natural competent. MuGENT allows for multiple scarless genome edits in one single step, but can also be employed sequentially to generate a heterogeneous population of mutants. As a proof of concept, the authors used the sequential transformation approach in order to increase production of the bioplastic PHB by a 100 fold.

Molecular tools in $V$. natriegens are relatively new, however, the outstanding characteristics of this bacterium have captured the attention of the community for further synthetic biology and cell factory applications. Furthermore, this promising cell factory belongs to a dominant group in the ocean surface waters: Vibrionaceae represent $1 \%$ of 
Proteobacteria. Marine vibrios have been demonstrated to natively produce numerous bioactives ${ }^{147,148}$ and $V$. natriegens could serve as a suitable host for those compounds.

\subsubsection{An upcoming evident marine Proteobacteria expression host: Pseudoalteromonas}

Pseudoalteromonas haloplanktis is an Antarctic Gram-negative bacterium able to circumvent the above-mentioned limitations and has been intensively investigated as expression host, particularly for recombinant proteins. ${ }^{149}$ Expression vectors with signal peptides have been reported to facilitate expression of $\alpha$-amylases of $P$. haloplanktis. ${ }^{141}$ The plasmid pFFamy containing the secreted $\alpha$-amylase gene was tested with three passenger proteins produced intracellularly from different hosts; indole-3-glycerol-phosphate synthase (SsIGPS) from Sulfolobus solfataricus, DsbA (PhDsbA) from P. haloplanktis, and the $\beta$-lactamase (EcBlaM) from $E$. coli. Plasmids were introduced by intergeneric conjugation. With these approaches, the authors achieve secreted expression in P. haloplanktis under psychrophilic conditions (4 ${ }^{\circ} \mathrm{C}$ ) facilitating slow protein folding. Additionally, P. haloplanktis has recently been demonstrated to natively produce anticancer-active 4-hydroxybenzoic acid. ${ }^{150}$ In a similar study, Yu et al..$^{74}$ developed a cold-adapted expression system in Pseudoalteromonas sp. BSi20429 and successfully expressed the active form of pseudoalterin, a cold-adapted enzyme. This was not possible in $E$. coli because of the lack of some enzymes in protein secretion systems. In this case, a new expression vector ( $\mathrm{pEV}$ ) was constructed with the native xylanase promoter and signal peptide from Pseudoalteromonas sp. SM20429.

Pseudoalterin was successfully produced in expression cultures at $15^{\circ} \mathrm{C}$ for $72 \mathrm{~h}$ and purified from the culture. These examples suggest that Pseudoaltermonas could become an attractive expression host for certain intractable proteins of marine origin and due to the vast bioactive potential of Pseudoalteromonas ${ }^{151}$ could be employed for the production of native or foreign secondary metabolites.

\subsubsection{Other future marine cell factories}

Today, marine Proteobacteria have been exploited for biotech production. Knowledge on them is growing fast to reach a level necessary for employment. The existing knowledge on terrestrial relatives can contribute to this aim. Marine Alphaproteobacteria have received little attention as heterologous production hosts and while being a rich source of novel natural products, ${ }^{148,152}$ the molecular tools for their modification are generally limited to knockouts. ${ }^{153,154}$ Their terrestrial relatives have been successfully assessed for the heterologous expression of natural products, e.g. the lasso peptide brevunsin by Sphingomonas subterranea ${ }^{155}$ or a triterpene in Rhodococcus capsulatus. ${ }^{156}$ Terrestrial Beta-, Gamma- and Deltaproteobacteria including the genera Burkholderia, ${ }^{157,158}$

Pseudomonas, ${ }^{68,120,159,160}$ and Myxococcus ${ }^{161}$ have been shown to be promising cell factories. Therefore, marine representatives of Proteobacteria could also be the candidates for future marine cell factories. Furthermore, it should also be considered if existing workhorses could be modulated to flourish at higher salt concentrations. While not prominent in the marine environment, $E$. coli can be found particularly close to harbors and wastewater outlets, ${ }^{162}$ which could push for a natural evolution of the species to high salt tolerance, and has also been demonstrated to be engineerable to an increased salt tolerance up to $1.54 \mathrm{M}^{163}$ 
In order to establish future cell factories, the criteria for the specific production process need to be carefully reviewed and accordingly, high throughput screening combining laboratory and computational research ${ }^{164}$ need to be applied to develop a dedicated cell factory for a natural product.

\subsection{Marine Proteobacteria in industrial biotech production}

The transition of a lab-based cell factory to a robust industrial strain is not a trivial one, but crucial for the development of a marine strain for large-scale production of natural products. Process economics become crucial, and saving on the production costs is a never-ending target. Marine Proteobacteria, and especially halophiles, possess a couple of characteristics that make them interesting to use in the biotech industry (see reference ${ }^{57}$ for a comprehensive review). Here, we focus on halophilic Proteobacteria for use in industrial biotech processes, and highlight a couple of success examples on secondary metabolite production.

Bio-based production processes suffer from high expenses caused by, among others, energy-intensive fermentations, a relative low productivity and large consumption of fresh water. ${ }^{165}$ Halophilic marine Proteobacteria can tolerate and thrive at high salt concentrations, which allows for replacing valuable fresh water with low-cost seawater in the fermentation broth. Usage of fresh water might currently not be a significant cost-driver in water-rich countries; however, some geographical locations already struggle with fresh water supply, a problem that will aggravate as the worldwide water consumption keeps swelling. ${ }^{166}$ However, currently there are still limitations regarding the use of seawater in fermentations, e.g. due to corrosion of stainless steel. ${ }^{167}$ A technical advancement or change in equipment and infrastructure seems to be necessary to support large-scale seawater-based processes.

A second benefit of using halophiles as production strains in fermentations is the reduced risk of contamination ${ }^{55,168}$, as non-halophiles do not proliferate in high-salt media. Contaminations can interfere with the stability and health of a production process and thus cause economic insecurity. Risk of contaminations can be lowered even further if the halophile is, for example, also able to grow at high $\mathrm{pH}$ (alkaliphilic) or a non-conventional substrate is used in the process. Moreover, the genetic background of halophilic Proteobacteria might be better suited for the biosynthesis of marine derived compounds. For example, the majority of halogenated natural products are marine derived, and many of these compounds possess biological activity. ${ }^{169}$ However, some marine derived brominated compounds were successfully produced in E. coli. ${ }^{26}$ Although this provides evidence that heterologous expression in non-marine bacteria can be achieved, it is difficult to extrapolate these results, as failures of similar approaches are generally not published.

Demonstration of the advantages of halophile-based fermentation processes were given by using Halomonas strains. ${ }^{170,171}$ In the most recent example, an alkaliphilic Halomonas campaniensis strain was used in an unsterile, continuous fermentation process for the production of PHB. ${ }^{171}$ Operating under high salt concentration and a $\mathrm{pH}$ of 10 , no significant contamination was detected for up to 65 days. Yield of PHB was improved by constructing a recombinant strain with the PHB BGC put under control of a strong promoter of a native porin. Synthetic biology efforts to control the morphology of the same H. campaniensis strain 
in a temperature-controlled matter showed a further improvement in PHB yield and productivity. ${ }^{172}$

Other examples of marine Proteobacteria studied to be used as production strains in industrial biotechnology setups involve the production of ectoine (5). Ectoine (5) is an osmoprotectant used by halophilic bacteria to counter the high osmolarity and is commercially used in the pharmaceutical industry. Halomonas elongata was engineered to produce ectoine (5) from mixed sugar substrates, simulating a lignocellulose-based bioprocess. ${ }^{47}$ Furthermore, it was demonstrated that rice straw hydrolysate could be used as substrate rendering the process economics much more favorable. ${ }^{173}$ The use of another lowcost substrate for ectoine (5) production was explored in a study with Methylomicrobium alcaliphilum. Methane, a potent greenhouse gas, was converted to ectoine (5) in an attempt to reduce greenhouse gas emission and simultaneously produce this valuable compound. ${ }^{48}$

Astaxanthin is a natural compound that belongs to the carotenoid family. Due to its potent antioxidant activity, astaxanthin has many applications in food, feed, and pharmaceuticals. ${ }^{43}$ A marine isolate of the Alphaproteobacterium Paracoccus was engineered for production of this high-value compound. ${ }^{44} \mathrm{~A}$ combination of random mutagenesis and overexpression of the native astaxanthin BGC from a broad-host-range vector resulted in a mutant with over 50 times higher astaxanthin production compared to the wild-type. The authors reported an astaxanthin titer of $480 \mathrm{mg} / \mathrm{L}$ and subsequently filed a patent. ${ }^{174}$ The concentration achieved with this Paracoccus strain is higher than the recently published astaxanthin titer from a heavily engineered $E$. coli strain. $^{42}$ This example shows that it could be more advantageous to choose a native producer strain over a traditional industrial workhorse organism.

These examples demonstrate the usefulness and potential of marine Proteobacteria as production strains in industrial biotechnology processes. Although most of these examples already involve some degree of genetic engineering, the continuous development of molecular tools for this group of bacteria will ensure a significant role of marine Proteobacteria on the biotechnology scene.

\section{CONCLUSION}

With up to $15 \%$ of their genomes dedicated to biosynthesis of secondary metabolites, marine Proteobacteria remain an attractive source of new drug leads. Also, the uncultivated "microbial dark matter" hidden in the ocean potentially increases the natural chemistry space even further. A crucial bottleneck in this research field is the lack of efficient genetic tractability in most marine Proteobacteria. Additionally, examples of producing marine bacterial BGCs in hosts such as E. coli are scarce, as heterologous expression of large clusters remains challenging. Recent improvements in genetic tools in marine proteobacterial cell factories are demonstrated by the emergence of $V$. natriegens in the field of molecular biology. These efforts will ultimately lead to a significant role of marine Proteobacteria in natural product discovery and the development of specialized hosts and cell factories for production of marine natural compounds.

\section{CONFLICTS OF INTEREST}

There are no conflicts to declare. 


\section{ACKNOWLEDGEMENTS}

This work was supported by the Danish National Research Foundation (DNRF137) for the Center for Microbial Secondary Metabolites. YB was supported by The Independent Research Fund Denmark (grant DFF - 7017-00003). PKB was supported by the Villum Yearly Award 2016 (for LG). MBT was supported by The Independent Research Fund Denmark (grant DFF - 8048-00035B). SDZ was supported by the European Union's Horizon 2020 research and innovation programme under the Marie Sklodowska-Curie grant agreement no. 713683 (COFUNDfellowsDTU) via the H.C. Ørsted fellowship programme. We sincerely acknowledge all of our colleagues for their work cited in this review.

\section{REFERENCES}

1 G. Mohanraj and T. Sekar, Int. J. Life Sci. Biotechnol. Pharma Res., 2013, 2, 114-126.

2 S. Parthasarathi, World J. Fish Mar. Sci., 2012, 4, 5-7.

3 P. R. Jensen, Trends Microbiol., 2016, 24, 968-977.

4 M. J. Fujita, N. Kimura, H. Yokose and M. Otsuka, Mol. BioSyst., 2012, 8, 482-485.

5 E. Kim, B. S. Moore and Y. J. Yoon, Nat. Chem. Biol., 2015, 11, 649-659.

6 G. Romano, M. Costantini, C. Sansone, C. Lauritano, N. Ruocco and A. Ianora, Mar. Environ. Res., 2017, 128, 58-69.

7 Y. López, V. Cepas and S. M. Soto, in Grand Challenges in Marine Biotechnology, eds. P. H. Rampelotto and A. Trincone, Springer, Cham, 1st edn., 2018, pp. 3-48.

8 S. K. Palanisamy, N. M. Rajendran and A. Marino, Nat. Products Bioprospect., 2017, 7, 1-111.

9 S. Perdicaris, T. Vlachogianni and A. Valavanidis, Nat. Prod. Chem. Res., 2013, 1, 2329-6836.

10 B. Pejin, A. G. Savic, A. Hegedis, I. Karaman, M. Horvatovic and M. Mojovic, Nat. Prod. Res., 2014, 28, 2057-2060.

11 C. Schinke, T. Martins, S. C. N. Queiroz, I. S. Melo and F. G. R. Reyes, J. Nat. Prod., 2017, 80, 1215-1228.

12 P. R. Jensen, B. S. Moore and W. Fenical, Nat. Prod. Rep., 2015, 32, 738-751.

13 D. J. Edwards, B. L. Marquez, L. M. Nogle, K. McPhail, D. E. Goeger, M. A. Roberts and W. H. Gerwick, Chem. Biol., 2004, 11, 817-33.

14 Z. Chang, N. Sitachitta, J. V. Rossi, M. A. Roberts, P. M. Flatt, J. Jia, D. H. Sherman and William H. Gerwick, J. Nat. Prod., 2004, 67, 1356-1367.

15 K. Kleigrewe, L. Gerwick, D. H. Sherman and W. H. Gerwick, Nat. Prod. Rep., 2016, 33, 348-364.

16 M. Mansson, L. Gram and T. O. Larsen, Mar. Drugs, 2011, 9, 1440-68.

17 H. Machado, E. C. Sonnenschein, J. Melchiorsen and L. Gram, BMC Genomics, 2015, 16, 158.

18 P. C. Still, T. A. Johnson, C. M. Theodore, S. T. Loveridge and P. Crews, J. Nat. Prod., 2014, 77, 690-702. 
19 M. L. Timmermans, Y. P. Paudel and A. C. Ross, Mar. Drugs, 2017, 15, 235.

20 S. S. Paulsen, M. L. Strube, P. K. Bech, L. Gram and E. C. Sonnenschein, mSystems, 2019, 4, e00060-19.

21 T. Piekarski, I. Buchholz, T. Drepper, M. Schobert, I. Wagner-Doebler, P. Tielen and D. Jahn, BMC Microbiol., 2009, 9, 265.

22 Z. Zeaiter, F. Mapelli, E. Crotti and S. Borin, Electron. J. Biotechnol., 2018, 33, 1728.

23 S. Chimalapati, M. de Souza Santos, K. Servage, N. J. De Nisco, A. B. Dalia and K. Orth, J. Bacteriol., 2018, 200, e00032-18.

24 G. D. N. Pearson and J. J. Mekalanos, Proc. Nati Acad. Sci. USA, 1982, 79, 29762980.

25 J. J. Zhang, X. Tang and B. S. Moore, Nat. Prod. Rep., 2019, 10.1039/C9NP00025A.

26 A. C. Ross, L. E. S. S. Gulland, P. C. Dorrestein and B. S. Moore, ACS Synth. Biol., 2014, 4, 414-420.

27 P. Cimermancic, M. H. Medema, J. Claesen, K. Kurita, L. C. Wieland Brown, K. Mavrommatis, A. Pati, P. A. Godfrey, M. Koehrsen, J. Clardy, B. W. Birren, E. Takano, A. Sali, R. G. Linington and M. A. Fischbach, Cell, 2014, 158, 412-421.

28 S. Sunagawa, L. P. Coelho, S. Chaffron, J. R. Kultima, K. Labadie, G. Salazar, B. Djahanschiri, G. Zeller, D. R. Mende, A. Alberti, F. M. Cornejo-Castillo, P. I. Costea, C. Cruaud, F. D’Ovidio, S. Engelen, I. Ferrera, J. M. Gasol, L. Guidi, F. Hildebrand, F. Kokoszka, C. Lepoivre, G. Lima-Mendez, J. Poulain, B. T. Poulos, M. Royo-Llonch, H. Sarmento, S. Vieira-Silva, C. Dimier, M. Picheral, S. Searson, S. Kandels-Lewis, C. Bowler, C. de Vargas, G. Gorsky, N. Grimsley, P. Hingamp, D. Iudicone, O. Jaillon, F. Not, H. Ogata, S. Pesant, S. Speich, L. Stemmann, M. B. Sullivan, J. Weissenbach, P. Wincker, E. Karsenti, J. Raes, S. G. Acinas, P. Bork, E. Boss, C. Bowler, M. Follows, L. Karp-Boss, U. Krzic, E. G. Reynaud, C. Sardet, M. Sieracki and D. Velayoudon, Science (80-. )., 2015, 348, 1261359-1261359.

29 S. A. Waksman, Proc. Natl. Acad. Sci. U. S. A., 1959, 45, 1043-1047.

30 K. Okamura, K. Soga, Y. Shimauchi, T. Ishikura and J. Lein, J. Antibiot. (Tokyo)., 1977, 30, 334-6.

31 M. Kenig and C. Reading, J. Antibiot. (Tokyo)., 1979, 32, 549-54.

32 Z. Qin, A. Thomas Baker, A. Raab, S. Huang, T. Wang, Y. Yu, M. Jaspars, C. J. Secombes and H. Deng, J. Biol. Chem., 2013, 288, $14688-14697$.

33 M. Wietz, M. Mansson, C. H. Gotfredsen, T. O. Larsen and L. Gram, Mar. Drugs, 2010, 8, 2946-2960.

34 P. Liras, Appl. Microbiol. Biotechnol., 2014, 98, 1023-1030.

35 B. Li, W. J. Wever, C. T. Walsh and A. A. Bowers, Nat. Prod. Rep., 2014, 31, 905923.

36 B. Li and C. T. Walsh, Biochemistry, 2011, 50, 4615-4622.

37 B. Li, R. R. Forseth, A. A. Bowers, F. C. Schroeder and C. T. Walsh, ChemBioChem, 2012, 13, 2521-2526. 
38 T. F. Molinski, D. S. Dalisay, S. L. Lievens and J. P. Saludes, Nat. Rev. Drug Discov., 2009, 8, 69-85.

39 F. Desriac, C. Jégou, E. Balnois, B. Brillet, P. Le Chevalier and Y. Fleury, Mar. Drugs, 2013, 11, 3632-3660.

40 A. Dávila-Céspedes, P. Hufendiek, M. Crüsemann, T. F. Schäberle and G. M. König, Beilstein J. Org. Chem., 2016, 12, 969-984.

41 C. Offret, F. Desriac, P. Le Chevalier, J. Mounier, C. Jégou and Y. Fleury, Mar. Drugs, 2016, 14, 129.

42 S. Y. Park, R. M. Binkley, W. J. Kim, M. H. Lee and S. Y. Lee, Metab. Eng., 2018, 49, $105-115$.

43 R. R. Ambati, P. S. Moi, S. Ravi and R. G. Aswathanarayana, Mar. Drugs, 2014, 12, $128-152$.

44 T. Ide, M. Hoya, T. Tanaka and S. Harayama, Biochem. Eng. J., 2012, 65, 37-43.

45 M. Speitling, O. F. Smetanina, T. A. Kuznetsova and H. Laatsch, J. Antibiot. (Tokyo)., 2007, 60, 36-42.

46 P. Boris, M. Miloš and G. S. Aleksandar, Biol. Serbica, 2014, 35, 3-14.

47 K. Tanimura, H. Nakayama, T. Tanaka and A. Kondo, Bioresour. Technol., 2013, 142, $523-529$.

48 S. Cantera, R. Lebrero, E. Rodríguez, P. A. García-Encina and R. Muñoz, J. Clean. Prod., 2017, 152, 134-141.

49 J. Severin, A. Wohlfarth and E. A. Galinslki, J. Gen. Microbiol., 1992, 138, 16291638.

50 U. Sydlik, H. Peuschel, A. Paunel-Görgülü, S. Keymel, U. Krämer, A. Weissenberg, M. Kroker, S. Seghrouchni, C. Heiss, J. Windolf, A. Bilstein, M. Kelm, J. Krutmann and K. Unfried, Eur. Respir. J., 2013, 41, 433-42.

51 R. Graf, S. Anzali, J. Buenger, F. Pfluecker and H. Driller, Clin. Dermatol., 2008, 26, 326-333.

52 Y. Sun, Z. Feng, T. Tomura, A. Suzuki, S. Miyano, T. Tsuge, H. Mori, J.-W. W. Suh, T. Iizuka, R. Fudou and M. Ojika, Sci. Rep., 2016, 6, 22091.

53 B. Li and C. T. Walsh, Proc. Natl. Acad. Sci. U. S. A., 2010, 107, 19731-5.

54 J. R. Chekan and B. S. Moore, Preparation and Characterization of

Tetrabromopyrrole Debrominase From Marine Proteobacteria, Elsevier Inc., 1st edn., 2018, vol. 605 .

55 X. Z. Fu, D. Tan, G. Aibaidula, Q. Wu, J. C. Chen and G. Q. Chen, Metab. Eng., 2014, 23, 78-91.

56 W. Tao, L. Lv and G.-Q. Chen, Microb. Cell Fact., 2017, 16, 48.

57 J. Yin, J. C. Chen, Q. Wu and G. Q. Chen, Biotechnol. Adv., 2015, 33, 1433-1442.

58 S. M. Salem, P. Kancharla, G. Florova, S. Gupta, W. Lu and K. A. Reynolds, J. Am. Chem. Soc., 2014, 136, 4565-4574.

59 P. Wang, Z. Yu, B. Li, X. Cai, Z. Zeng, X. Chen and X. Wang, Microb. Cell Fact., 2015, 14, 11. 
60 A. Nielsen, M. Man̊sson, M. S. Bojer, L. Gram, T. O. Larsen, R. P. Novick, D. Frees, H. Frøkiær and H. Ingmer, PLoS One, 2014, 9, e84992.

61 H. Machado, M. Månsson and L. Gram, Genome Announc., 2014, 2, 9-10.

62 D. Fukuda, A. S. Haines, Z. Song, A. C. Murphy, J. Hothersall, E. R. Stephens, R. Gurney, R. J. Cox, J. Crosby, C. L. Willis, T. J. Simpson and C. M. Thomas, PLoS One, 2011, 6, e18031.

63 B. B. Rasmussen, K. E. Erner, M. Bentzon-Tilia and L. Gram, Microb. Biotechnol., 2018, 11, 1070-1079.

64 H. Geng, J. B. Bruhn, K. F. Nielsen, L. Gram and R. Belas, Appl. Environ. Microbiol., 2008, 74, 1535-1545.

65 M. Bentzon-Tilia and L. Gram, in Biotechnological Applications of the Roseobacter Clade, eds. R. Paterson and N. Lima, Springer International Publishing, 2017, pp. 137166.

66 E. E. Wyckoff, J. A. Stoebner, K. E. Reed and S. M. Payne, J. Bacteriol., 1997, 179, 7055-7062.

67 S. F. Brady, C. J. Chao, J. Handelsman and J. Clardy, Org. Lett., 2001, 3, 1981-1983.

68 J. J. Zhang, X. Tang, M. Zhang, D. Nguyen and B. S. Moore, MBio, 2017, 8, e0129117.

69 T. Ma, Y. Zhou, X. Li, F. Zhu, Y. Cheng, Y. Liu, Z. Deng and T. Liu, Biotechnol. J., 2016, 11, 228-237.

70 G. C. A. Amos, T. Awakawa, R. N. Tuttle, A.-C. Letzel, M. C. Kim, Y. Kudo, W. Fenical, B. S. Moore and P. R. Jensen, Proc. Natl. Acad. Sci., 2017, 114, E11121E11130.

71 S. Giubergia, C. Phippen, K. F. Nielsen and L. Gram, mSystems, 2017, 2, e00141-1.

72 N. Adnani, S. R. Rajski and T. S. Bugni, Nat. Prod. Rep., 2017, 34, 784-814.

73 K. A. Reynolds, H. Luhavaya, J. Li, S. Dahesh, V. Nizet, K. Yamanaka and B. S. Moore, J. Antibiot. (Tokyo)., 2018, 71, 333-338.

74 Z. C. Yu, B. L. Tang, D. L. Zhao, X. Pang, Q. L. Qin, B. C. Zhou, X. Y. Zhang, X. L. Chen and Y. Z. Zhang, PLoS One, 2015, 10, e0137384.

75 S. Sengupta, M. K. Chattopadhyay and H.-P. Grossart, Front. Microbiol., 2013, 4, 47.

76 P. A. Kozhevin, K. A. Vinogradova and V. G. Bulgakova, Moscow Univ. Soil Sci. Bull., 2014, 69, 93-98.

77 D. Mao, B. K. Okada, Y. Wu, F. Xu and M. R. Seyedsayamdost, Curr. Opin. Microbiol., 2018, 45, 156-163.

78 K. L. Meibom, M. Blokesch, N. A. Dolganov, C. Y. Wu and G. K. Schoolnik, Science (80-. )., 2005, 310, 1824-1827.

79 Y. Chen, J. Dai, J. G. Morris, J. A. Johnson and J. A. Johnson, BMC Microbiol., 2010, 10, 274.

80 P. A. Gulig, M. S. Tucker, P. C. Thiaville, J. L. Joseph and R. N. Brown, Appl. Environ. Microbiol., 2009, 75, 4936-49. 
81 A. Pollack-Berti, M. S. Wollenberg and E. G. Ruby, Environ. Microbiol., 2010, 12, 2302-11.

L. Gram, J. Melchiorsen and J. Bruhn, Mar. Biotechnol., 2010, 12, 439-451.

83 H. Marcus, J. M. Ketley, J. B. Kaper and R. K. Holmes, FEMS Microbiol. Lett., 1990, 68, 149-154.

84 M. T. Weinstock, E. D. Hesek, C. M. Wilson and D. G. Gibson, Nat. Methods, 2016, 13, 849-851.

85 N. Wu, K. Matand, B. Kebede, G. Acquaah and S. Williams, Electron. J. Biotechnol., 2010, 13, 21-22.

86 K. Yamanaka, J. Mol. Microbiol. Biotechnol, 1999, 1, 193-202.

87 F. Delavat, A. Bidault, V. Pichereau and C. Paillard, J. Microbiol. Methods, 2018, 154, $1-5$.

88 J. M. Vraspir and A. Butler, Ann. Rev. Mar. Sci., 2008, 1, 43-63.

89 F. J. De Bruijn and J. R. Lupski, Gene, 1984, 27, 131-149.

90 D. P. Henderson and S. M. Payne, Mol. Microbiol., 1993, 7, 461-469.

91 P. W. D’Alvise, J. Melchiorsen, C. H. Porsby, K. F. Nielsen and L. Gram, Appl. Environ. Microbiol., 2010, 76, 2366-70.

92 T. Grotkjær, M. Bentzon-Tilia, P. W. D’Alvise, N. Dourala, K. F. Nielsen and L. Gram, Syst. Appl. Microbiol., 2016, 39, 180-188.

93 B. B. Rasmussen, T. Grotkjær, P. W. D’Alvise, G. Yin, F. Zhang, B. Bunk, C. Spröer, M. Bentzon-Tilia and L. Gram, Appl. Environ. Microbiol., 2016, 82, 4802-4810.

94 C. H. Porsby, M. A. Webber, K. F. Nielsen, L. J. V Piddock and L. Gram, Antimicrob. Agents Chemother., 2011, 55, 1332-1337.

95 T. R. Miller and R. Belas, Environ. Microbiol., 2006, 8, 1648-1659.

96 P. Luo, X. He, Q. Liu and C. Hu, PLoS One, 2015, 10, e0144465.

97 A. K. El-Sayed, J. Hothersall and C. M. Thomas, Microbiology, 2001, 147, 21272139.

98 A. Schäfer, A. Tauch and A. Pühler, Gene, 1994, 145, 1-11.

99 M. E. Kovach, P. H. Elzer, D. Steven Hill, G. T. Robertson, M. A. Farris, R. M. Roop and K. M. Peterson, Gene, 1995, 166, 175-176.

100 S. T. Lam, B. S. Lam and G. Strobel, Plasmid, 1985, 13, 200-204.

101 G. Pósfai, V. Kolisnychenko, Z. Bereczki and F. R. Blattner, Nucleic Acids Res., 1999, 27, 4409-4415.

102 L. S. Qi, M. H. Larson, L. A. Gilbert, J. A. Doudna, J. S. Weissman, A. P. Arkin and W. A. Lim, Cell, 2013, 152, 1173-1183.

103 Q.-J. Yin, W.-J. Zhang, X.-Q. Qi, S.-D. Zhang, T. Jiang, X.-G. Li, Y. Chen, C.-L. Santini, H. Zhou, I.-M. Chou and L.-F. Wu, Front. Microbiol., 2017, 8, 2646.

104 C. Zhang and S.-K. Kim, Mar. Drugs, 2010, 8, 1920-1934.

105 G. Feller, F. Payan, F. Theys, M. Qian, R. Haser and C. Gerday, Eur. J. Biochem., 1994, 222, 441-447. 
106 C. Vickers, F. Liu, K. Abe, O. Salama-Alber, M. Jenkins, C. M. K. Springate, J. E. Burke, S. G. Withers and A. B. Boraston, J. Biol. Chem., 2018, 293, 18296-18308.

107

108 H.-J. Nah, H.-R. Pyeon, S.-H. Kang, S.-S. Choi and E.-S. Kim, Front. Microbiol., $2017,8,394$.

109 G. W. Gribble, Environ. Sci. Pollut. Res., 2000, 7, 37-49.

110 P. R. Burkholder, R. M. Pfister and F. H. Leitz, APPUED Microbiol., 1966, 14, 649653.

111 A. Isnansetyo and Y. Kamei, Antimicrob. Agents Chemother., 2003, 47, 480-488.

112 R. J. Andersen, M. . Wolfe and D. J. Faulkner, Mar. Biol., 1974, 27, 281-285.

113 V. Agarwal, A. A. El Gamal, K. Yamanaka, D. Poth, R. D. Kersten, M. Schorn, E. E. Allen and B. S. Moore, Nat. Chem. Biol., 2014, 10, 640-647.

114 T. L. Orr-Weaver, J. W. Szostak and R. J. Rothstein, Proc. Natl. Acad. Sci. U. S. A., 1981, 78, 6354-8.

115 K. Terpe, Appl. Microbiol. Biotechnol., 2006, 72, 211-222.

116 N. I. Kalinovskaya, A. S. Dmitrenok, T. A. Kuznetsova, G. M. Frolova, R. Christen, H. Laatsch, Y. V. Alexeeva and E. P. Ivanova, Curr. Microbiol., 2008, 56, 199-207.

117 V. Agarwal, A. A. El Gamal, K. Yamanaka, D. Poth, R. D. Kersten, M. Schorn, E. E. Allen and B. S. Moore, Nat. Chem. Biol., 2014, 10, 640-647.

118 C. Greunke, E. R. Duell, P. M. D’Agostino, A. Glöckle, K. Lamm and T. A. M. Gulder, Metab. Eng., 2018, 47, 334-345.

119 O. Perlova, J. Fu, S. Kuhlmann, D. Krug, A. F. Stewart, Y. Zhang and R. Müller, Appl. Environ. Microbiol., 2006, 72, 7485-7494.

120 A. Loeschcke and S. Thies, Appl. Microbiol. Biotechnol., 2015, 99, 6197-6214.

121 F. Gross, D. Gottschalk and R. Müller, Appl. Microbiol. Biotechnol., 2005, 68, 66-74.

122 C. A. Brotherton, M. H. Medema and E. P. Greenberg, mSystems, 2018, 3, e00208-17.

123 K. J. Weissman and R. Müller, Nat. Prod. Rep., 2010, 27, 1276-1295.

124 T. F. Schäberle, E. Goralski, E. Neu, Ö. Erol, G. Hölzl, P. Dörmann, G. Bierbaum and G. M. König, Mar. Drugs, 2010, 8, 2466-2479.

125 A. S. Razumov, Mikrobiologija, 1932, 1, 131-146.

126 Z. Charlop-Powers, J. G. Owen, B. V. B. Reddy, M. A. Ternei and S. F. Brady, Proc. Natl. Acad. Sci. U. S. A., 2014, 111, 3757-62.

127 Z. Charlop-Powers, C. C. Pregitzer, C. Lemetre, M. A. Ternei, J. Maniko, B. M. Hover, P. Y. Calle, K. L. McGuire, J. Garbarino, H. M. Forgione, S. Charlop-Powers and S. F. Brady, Proc. Natl. Acad. Sci., 2016, 113, 14811-14816.

128 M. Katz, B. M. Hover and S. F. Brady, J. Ind. Microbiol. Biotechnol., 2016, 43, 129 141.

129 B. M. Hover, S.-H. Kim, M. Katz, Z. Charlop-Powers, J. G. Owen, M. A. Ternei, J. Maniko, A. B. Estrela, H. Molina, S. Park, D. S. Perlin and S. F. Brady, Nat. Microbiol., 2018, 3, 415-422. 
130 S. F. Brady, C. J. Chao and J. Clardy, J. Am. Chem. Soc., 2002, 124, 9968-9969.

131 D. E. Gillespie, S. F. Brady, A. D. Bettermann, N. P. Cianciotto, M. R. Liles, M. R. Rondon, J. Clardy, R. M. Goodman and J. Handelsman, Appl. Environ. Microbiol., 2002, 68, 4301-6.

132a D.-X. Kong, Y.-Y. Jiang and H.-Y. Zhang, Drug Discov. Today, 2010, 15, 884-886.

132b J. W. Blunt and M. H. G. Munro, Dictionary of Marine Natural Products, Chapman \& Hall/CRC, Boca Raton, FL, USA, 2008.

http://dmnp.chemnetbase.com/faces/chemical/ChemicalSearch.xhtml (Accessed 29 August 2019)

133 S. K. Davidson, S. W. Allen, G. E. Lim, C. M. Anderson and M. G. Haygood, Appl. Environ. Microbiol., 2001, 67, 4531-4537.

134 M. Hildebrand, L. E. Waggoner, H. Liu, S. Sudek, S. Allen, C. Anderson, D. H. Sherman and M. Haygood, Chem. Biol., 2004, 11, 1543-52.

135 M. Trindade, L. J. van Zyl, J. Navarro-Fernández and A. A. Elrazak, Front. Microbiol., 2015, 6, 890.

136 J. A. L. Garcia, A. Fernández-Guerra and E. O. Casamayor, Mol. Phylogenet. Evol., 2011, 61, 650-658.

137 E. W. Schmidt, J. T. Nelson, D. A. Rasko, S. Sudek, J. A. Eisen, M. G. Haygood and J. Ravel, Proc. Natl. Acad. Sci., 2005, 102, 7315-7320.

138 L. Jørgensen, S. J. McKerrall, C. A. Kuttruff, F. Ungeheuer, J. Felding and P. S. Baran, Science (80-. )., 2013, 341, 878-882.

139 M. Sauer and D. Mattanovich, J. Chem. Technol. Biotechnol., 2012, 87, 445-450.

140 P. Calero and P. I. Nikel, Microb. Biotechnol., 2018, 0, 1-27.

141 A. Cusano, E. Parrilli, G. Marino and M. L. Tutino, Microb. Cell Fact., 2006, 5, 40.

142 W. J. Payne, R. G. Eagon and A. K. Williams, Antonie Van Leeuwenhoek, 1961, 27, 121-128.

143 E. Hoffart, S. Grenz, J. Lange, R. Nitschel, F. Müller, A. Schwentner, A. Feith, M. Lenfers-Lücker, R. Takors and B. Blombach, Appl. Environ. Microbiol., 2017, 83, e01614-17.

144 Synthetic Genomics Launches Vmax ${ }^{\mathrm{TM}}$ Express, a Next-Generation Protein Expression Platform for the Biotech Industry - Synthetic Genomics, Inc, https://www.syntheticgenomics.com/synthetic-genomics-launches-vmax-express-anext-generation-protein-expression-platform-for-the-biotech-industry/, (Accessed 7 February 2019).

145 H. H. Lee, N. Ostrov, M. A. Gold and G. M. Church, bioRxiv, 2017, 130088.

146 T. N. Dalia, C. A. Hayes, S. Stolyar, C. J. Marx, J. B. McKinlay and A. B. Dalia, ACS Synth. Biol., 2017, 6, 1650-1655.

147 B. B. Rasmussen, K. F. Nielsen, H. Machado, J. Melchiorsen, L. Gram and E. C. Sonnenschein, Mar. Drugs, 2014, 12, 5527-46.

148 M. Wietz, M. Månsson, N. G. Vynne and L. Gram, in Marine Microbiology: Bioactive Compounds and Biotechnological Applications, 2013, pp. 127-159. 
149 E. Parrilli and M. L. Tutino, in Psychrophiles: From Biodiversity to Biotechnology: Second Edition, 2017, pp. 513-525.

150 F. Sannino, C. Sansone, C. Galasso, S. Kildgaard, P. Tedesco, R. Fani, G. Marino, D. De Pascale, A. Ianora, E. Parrilli, T. O. Larsen, G. Romano and M. L. Tutino, Sci. Rep., 2018, 8, 1190.

151 S. S. Paulsen, M. L. Strube, P. K. Bech, L. Gram and E. C. Sonnenschein, mSystems, 2019, 4, e00060-19.

152 E. C. Sonnenschein, C. B. W. Phippen, M. Bentzon-Tilia, S. A. Rasmussen, K. F. Nielsen and L. Gram, Environ. Microbiol. Rep., 2018, 10, 383-393.

153 R. Wang, É. Gallant and M. R. Seyedsayamdost, MBio, 2016, 7, e02118-15.

154 J. Zan, O. Choi, H. Meharena, C. L. Uhlson, M. E. a Churchill, R. T. Hill and C. Fuqua, Microbiology, 2015, 161, 50-6.

155 S. Kodani, H. Hemmi, Y. Miyake, I. Kaweewan and H. Nakagawa, J. Ind. Microbiol. Biotechnol., 2018, 45, 983-992.

156 A. Loeschcke, D. Dienst, V. Wewer, J. Hage-Hülsmann, M. Dietsch, S. Kranz-Finger, V. Hüren, S. Metzger, V. B. Urlacher, T. Gigolashvili, S. Kopriva, I. M. Axmann, T. Drepper and K. E. Jaeger, PLoS One, 2017, 12, e0189816.

157 A. S. Eustáquio, L. P. Chang, G. L. Steele, C. J. O’Donnell and F. E. Koehn, Metab. Eng., 2016, 33, 67-75.

158 C. Kourmentza, J. Costa, Z. Azevedo, C. Servin, C. Grandfils, V. De Freitas and M. A. M. Reis, Bioresour. Technol., 2018, 247, 829-837.

159 E. Martínez-García, P. I. Nikel, T. Aparicio and V. de Lorenzo, Microb. Cell Fact., 2014, 13, 159.

160 K. Gemperlein, M. Hoffmann, L. Huo, P. Pilak, L. Petzke, R. Müller and S. C. Wenzel, Metab. Eng., 2017, 44, 213-222.

161 H. Sucipto, D. Pogorevc, E. Luxenburger, S. C. Wenzel and R. Müller, Metab. Eng., 2017, 44, 160-170.

162 R. Drali, M. Berrazeg, L. L. Zidouni, F. Hamitouche, A. A. Abbas, A. Deriet and F. Mouffok, Sci. Total Environ., 2018, 642, 90-94.

163 Y. Guo, Y. Dong, X. Hong, X. Pang, D. Chen and X. Chen, Int. J. Mol. Sci., 2016, 17, $1-13$.

164 Z. A. King, J. Lu, A. Dräger, P. Miller, S. Federowicz, J. A. Lerman, A. Ebrahim, B. O. Palsson and N. E. Lewis, Nucleic Acids Res., 2016, 44, 515-522.

165 G. Q. Chen, Microb. Cell Fact., 2012, 11, 2-4.

166 M. A. Hanjra and M. E. Qureshi, Food Policy, 2010, 35, 365-377.

167 E. Torsner, Corros. Eng. Sci. Technol., 2010, 45, 42-48.

168 H. Yue, C. Ling, T. Yang, X. Chen, Y. Chen, H. Deng, Q. Wu, J. Chen and G. Q. Chen, Biotechnol. Biofuels, 2014, 7, 1-12.

169 G. W. Gribble, Mar. Drugs, 2015, 13, 4044-4136.

170 D. Tan, Y. S. Xue, G. Aibaidula and G. Q. Chen, Bioresour. Technol., 2011, 102, 8130-8136. 
171 H. Yue, C. Ling, T. Yang, X. Chen, Y. Chen, H. Deng, Q. Wu, J. Chen and G. Q. Chen, Biotechnol. Biofuels, 2014, 7, 1-12.

172 X. R. Jiang, Z. H. Yao and G. Q. Chen, Metab. Eng., 2017, 44, 30-37.

173 R. Kumar, S. Singh and O. V. Singh, J. Ind. Microbiol. Biotechnol., 2008, 35, 377391.

174 US 8,883,969 B2, 2014.

175 C. P. Long, J. E. Gonzalez, R. M. Cipolla and M. R. Antoniewicz, Metab. Eng., 2017, 44, 191-197.

176 H. Fernández-Llamosas, L. Castro, M. L. Blázquez, E. Díaz and M. Carmona, Sci. Rep., 2017, 7, 16046. 


\section{Figures:}

RSC Author Templates - ChemDraw (CDX) - Double Column Artwork

All text and images must be placed within the frame.

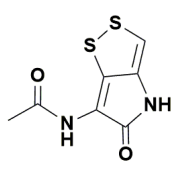

Holomycin (1)

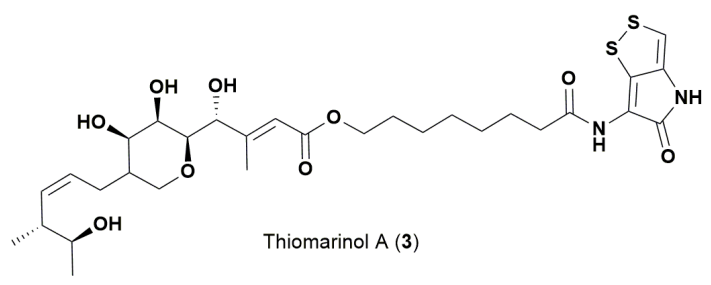

Tropodithietic acid (TDA) (2)

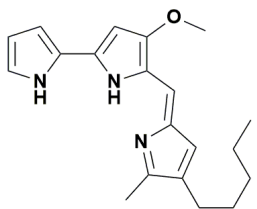

$$
\overbrace{\mathrm{CH}_{3}}^{\mathrm{OH}}
$$

Ectoine (5)

Prodigiosin (4)

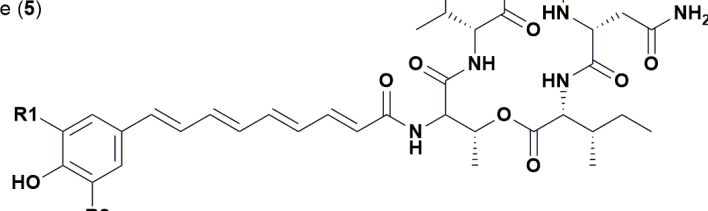

R2

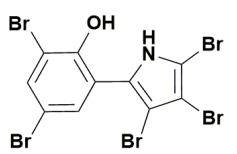

Pentabromopseudilin (6)

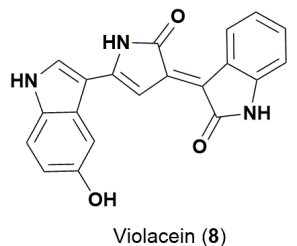

Violacein (8)

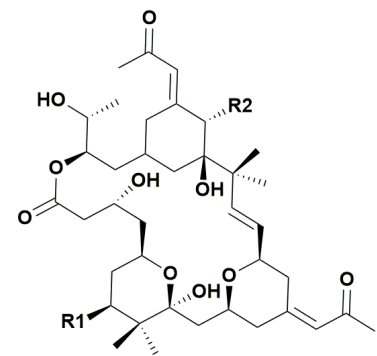

Bryostatin 1 (10a): R1=OAc. R2 $=\mathrm{OCO}(\mathrm{CH})_{4} \mathrm{CH}_{2} \mathrm{CH}_{2} \mathrm{CH}_{3}$

Bryostatin 2 (10b): R1 $=\mathrm{OH}$. R2 $=\mathrm{OCO}(\mathrm{CH})_{4} \mathrm{CH}_{2} \mathrm{CH}_{2} \mathrm{CH}_{3}$ Bryostatin 7 (10c): R1=OAc. R2=OAc

(10) Alterochromide $(7 \mathbf{a}): \mathrm{R} 2=\mathrm{H}$
Bromoalterochromide $\mathrm{A}(\mathbf{7 b}): \mathrm{R} 1=\mathrm{H}, \mathrm{R} 2=\mathrm{Br}$
Dibromoalterochromide $\mathrm{A}(\mathbf{7 c}): \mathrm{R} 1=\mathrm{Br}, \mathrm{R} 2=\mathrm{Br}$ (7)

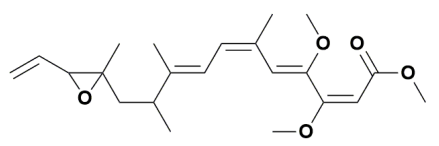

Haliangicin (9)

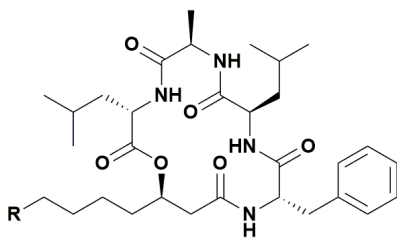

Solonamide A (11a): $\mathrm{R}=\mathrm{H}$ Solonamide $\mathrm{B}$ (11b): $\mathrm{R}=\mathrm{CH}_{2} \mathrm{CH}_{3}$ (11)

Figure 1. Selected bioactive compounds from marine Proteobacteria. 
<smiles>Brc1[nH]c(Br)c(Br)c1Br</smiles>

(12)<smiles>Oc1ccc(Br)cc1-c1cc(Br)cc(Br)c1O</smiles>

(13)<smiles>Oc1ccc(Oc2ccc(Br)cc2Br)cc1Br</smiles>

(14)<smiles>Oc1c(Br)cc(Oc2ccc(Br)cc2Br)cc1Br</smiles>

(15)<smiles>Oc1c(Br)cc(Br)cc1Oc1ccc(Br)cc1Br</smiles>

(16)

b

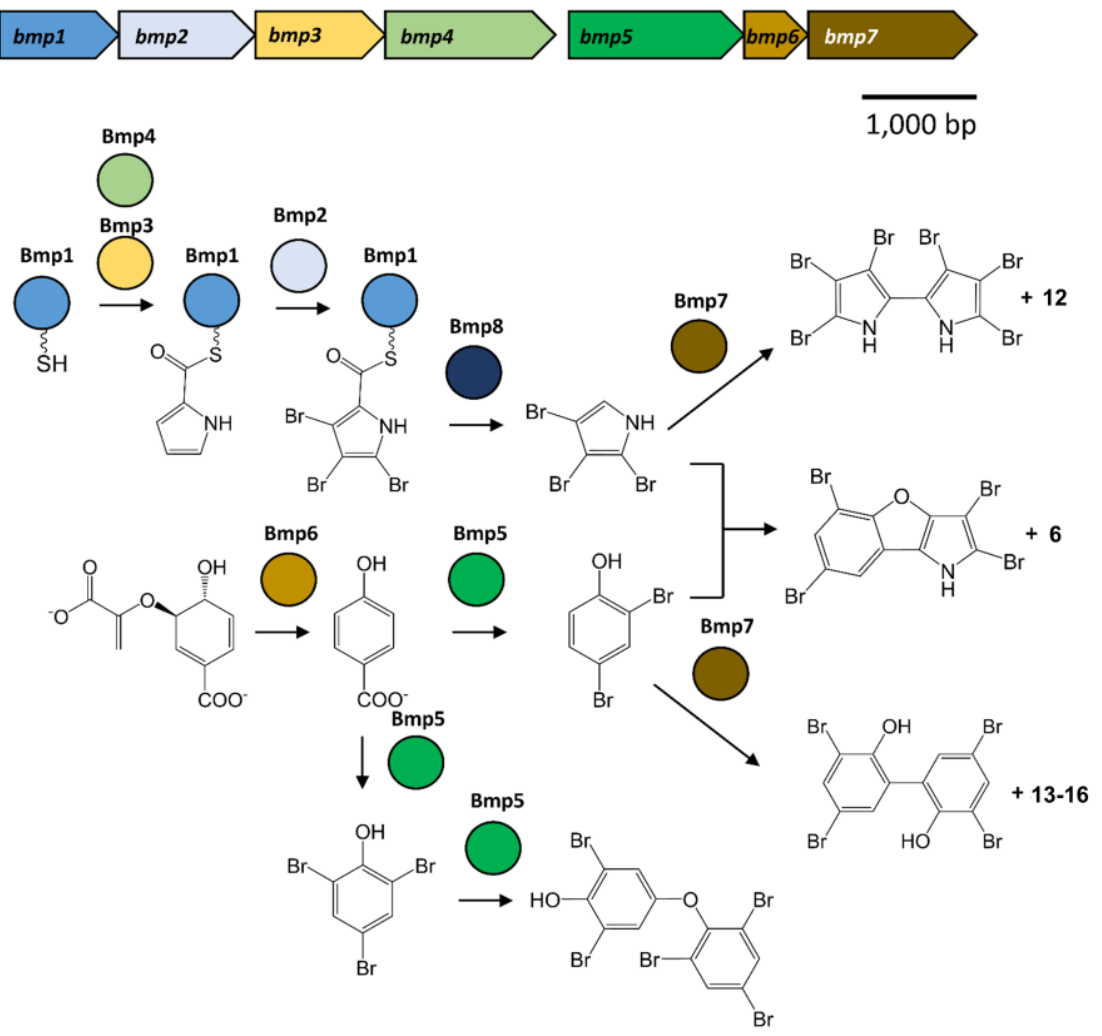

Figure 2. Biosynthesis of polybrominated aromatic compounds from the marine Gammaproteobacteria P. luteoviolacea 2ta16. (a) Polybrominated diphenyl esters produced by $P$. luteoviolacea 2 ta16 and (b) the biosynthesis of the natural products by the $b m p$ pathway. Figure modified from Agarwal et al. ${ }^{117}$ Adapted by permission from Springer Nature Customer Service Centre GmbH: Springer Nature, Nature Chemical Biology, Biosynthesis of polybrominated aromatic organic compounds by marine bacteria, ${ }^{117}$ Vinayak Agarwal, Abrahim A El Gamal, Kazuya Yamanaka, Dennis Poth, Roland D Kersten, Michelle Schorn, Eric E Allen and Bradley S Moore, Copyright (2014). 


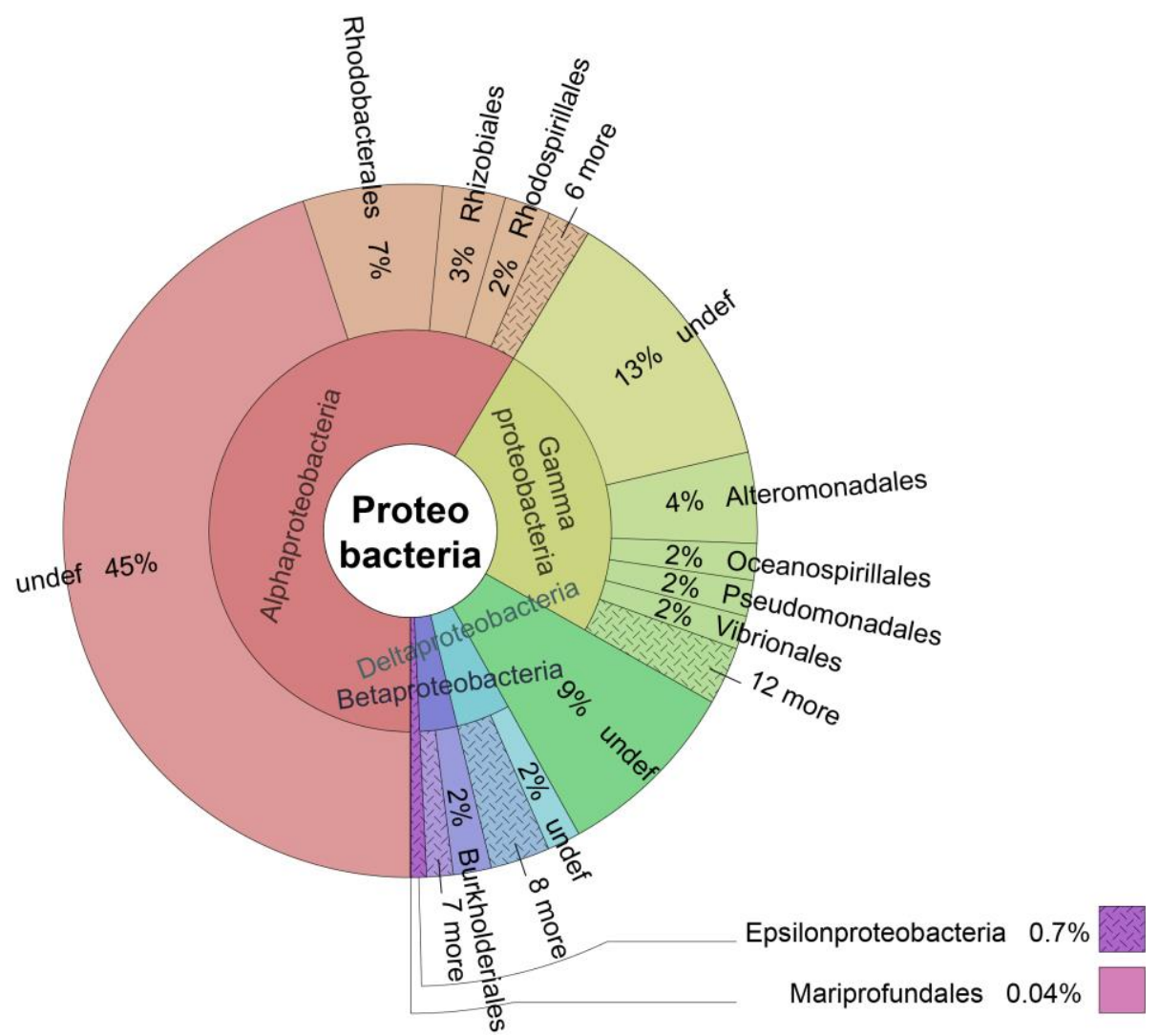

Figure 3. Abundances of marine Proteobacteria in marine surface waters as identified in the TARA Ocean dataset. ${ }^{28}$ 


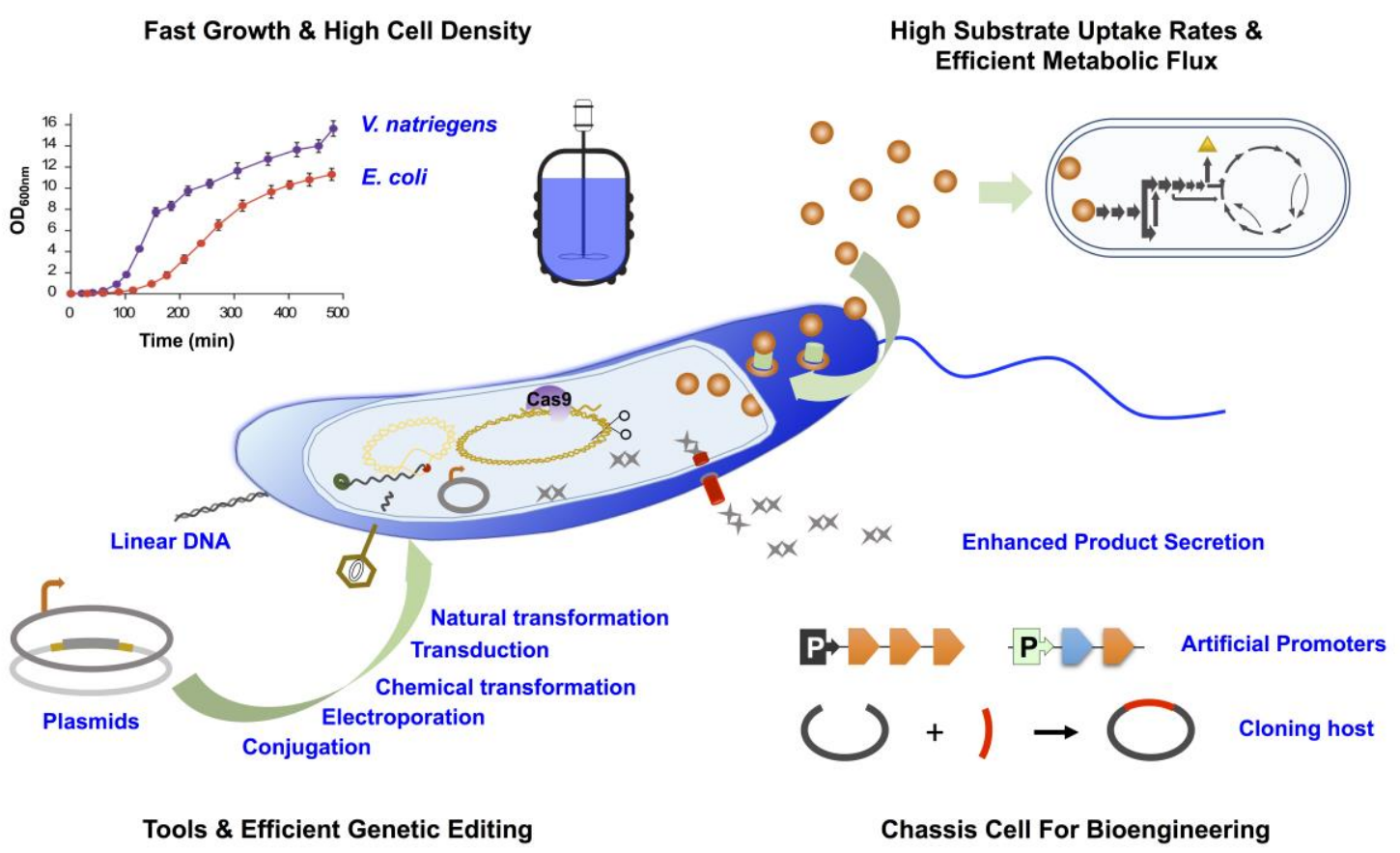

Figure 4. V. natriegens as the new proteobacterial powerhouse. Figure modified from ${ }^{84,143-146,175,176}$ Fast Growth \& High Cell Density: Adapted by permission from Springer Nature Customer Service Centre GmbH: Springer Nature, Nature Methods, Vibrio natriegens as a fast-growing host for molecular biology, ${ }^{84}$ Matthew T Weinstock, Eric D Hesek, Christopher M Wilson, Daniel G Gibson, Copyright (2016).

High Substrate Uptake Rates \& Efficient metabolic Flux: Reprinted from Metabolic Engineering: 44, Christopher P. Long, Jacqueline E. Gonzalez, Robert M. Cipolla, Maciek R. Antoniewicz, Metabolism of the fast-growing bacterium Vibrio natriegens elucidated by ${ }^{13} \mathrm{C}$ metabolic flux analysis, ${ }^{175}$ 191-197, Copyright (2017), with permission from Elsevier. 